$$
\begin{gathered}
\text { UNIVERSITY OF CALIFORNIA } \\
\text { COLLEGE OF AGRICULTURE } \\
\text { AGRICULTURAL EXPERIMENT STATION } \\
\text { BERKELEY, CALIFORNIA }
\end{gathered}
$$

\title{
CATERPILLARS ATTACKING TOMATOES
}

\author{
A. E. MICHELBACHER AND E. O. ESSIG
}

\section{BULLETIN 625}

\author{
JULY, 1938
}




\section{CONTENTS}

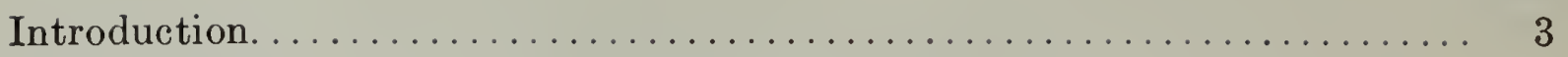

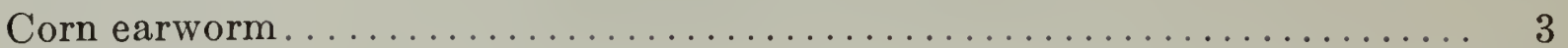

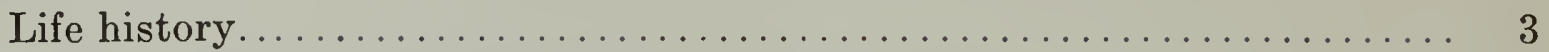

Insects commonly confused with the corn earworm ............. 5

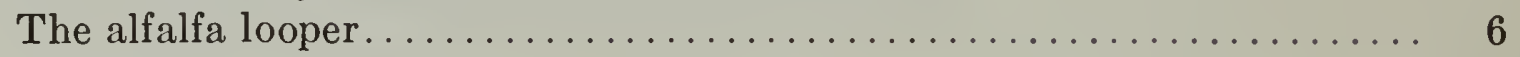

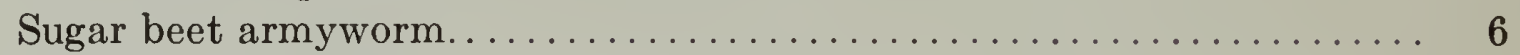

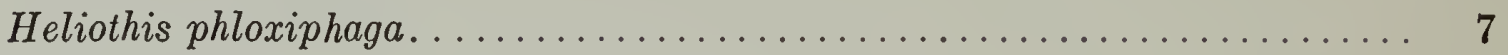

Destructiveness...................................... 8

Host range and host preference.......................... 9

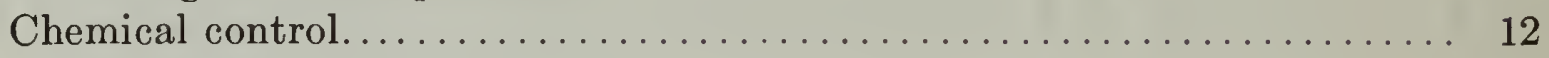

Previous work with arsenicals. . . . . . . . . . . . . . . . 12

Experimental work with calcium arsenate, lead arsenate, cryolite, barium fluosilicate, and sodium fluosilicate.................. 12

Experimental work with phenothiazine, Kutane, and calcium arsenate... 15

Experimental work with pyrethrum, derris, and Epsom salts......... 17

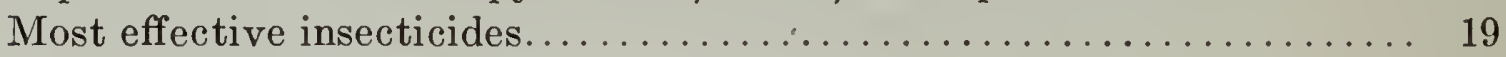

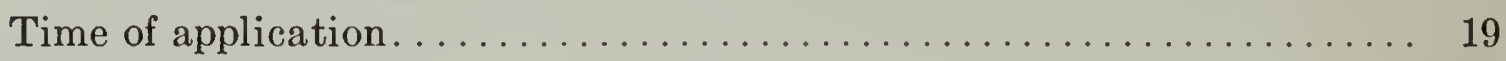

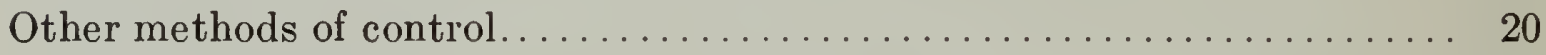

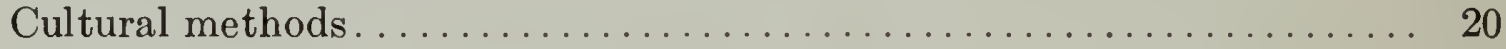

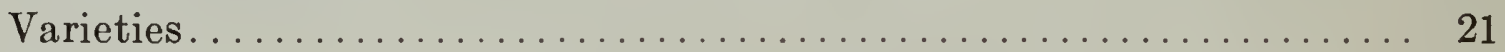

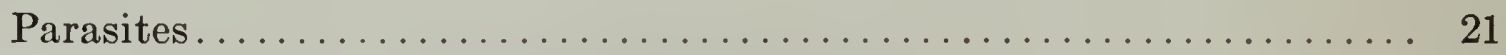

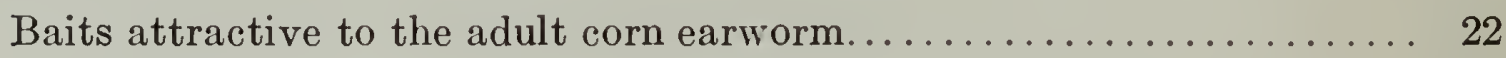

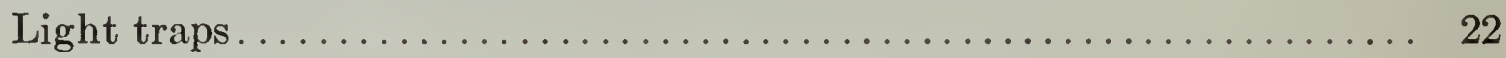

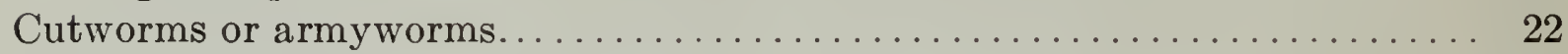

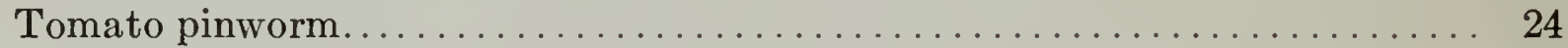

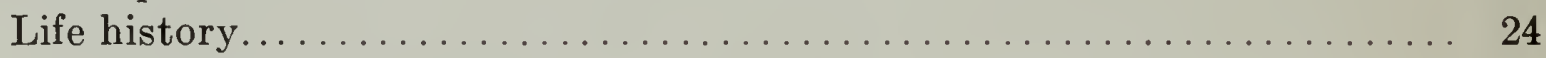

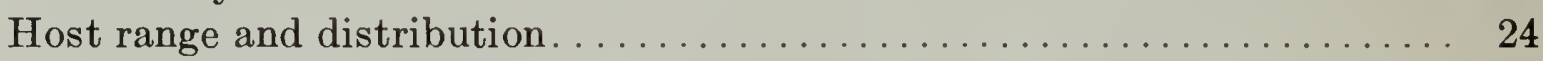

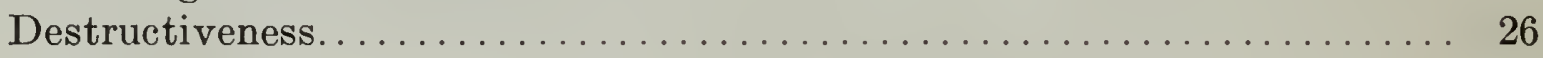

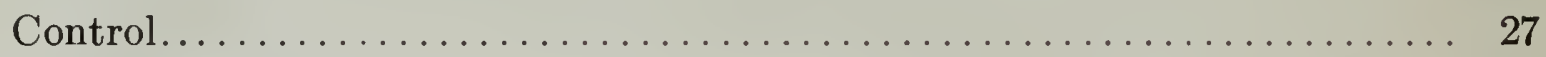

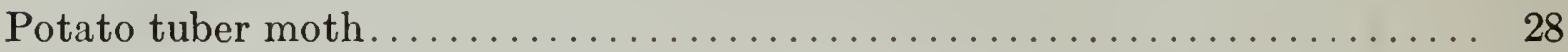

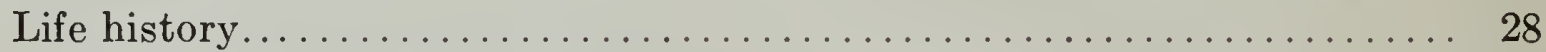

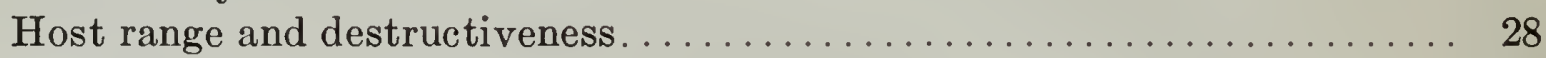

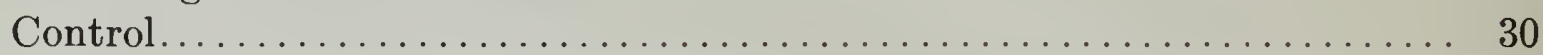

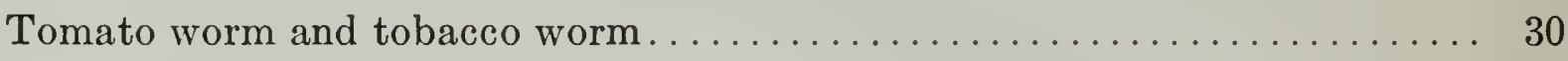

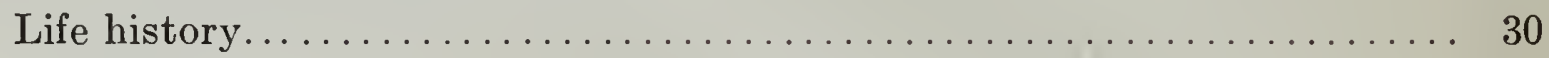

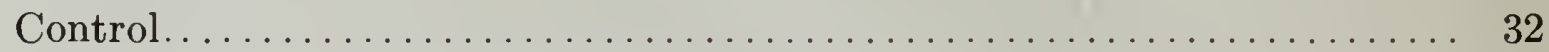

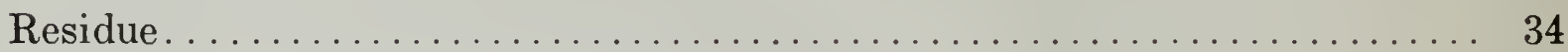

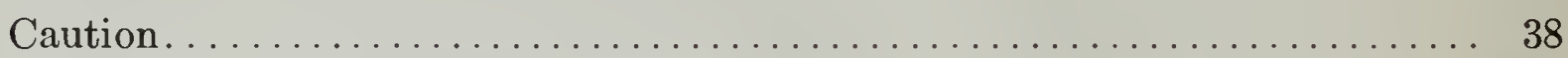

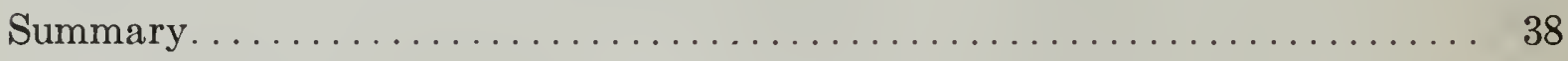

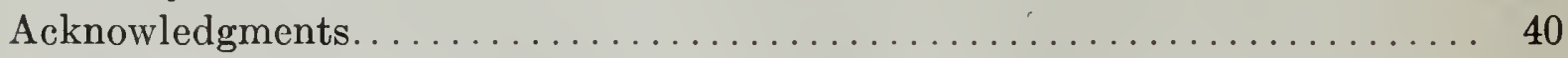

Literature cited.................................... 41 


\title{
CATERPILLARS ATTACKING TOMATOES ${ }^{1,2}$
}

\author{
A. E. MICHELBACHER ${ }^{3}$ AND E. O. ESSIG ${ }^{4}$
}

\section{INTRODUCTION}

Although INVESTIGations for the control of the corn earworm have been conducted on various crops for many years, the actual accumulated data with reference to controlling this pest and other caterpillars on tomatoes are very meager. Because of the seriousness of the insect on tomatoes in California, an extensive study has been conducted over a period of two and one-half years to determine its biology and methods of combating its ravages on this important crop. During one of these years it occurred in what is probably about average abundance and during another it occurred in abnormal numbers in the Sacramento Valley. So much information of value to growers has been obtained that a progress report seems advisable at this time.

Many phases of the problem require further investigation, particularly in connection with larval baits, bait traps, and light traps. A further search for effective insecticides less poisonous to man than those now in use and for more efficient methods of the application of insecticides in general is urgent.

This investigation has been limited to the northern tomato-growing sections of the state and the results and conclusions are based upon these findings. The problems of the tomato growers in southern California are undoubtedly different from those encountered in this area; these problems are being investigated by the United States Department of Agriculture Bureau of Entomology and Plant Quarantine at Alhambra.

\section{CORN EARWORM}

\section{LIFE HISTORY}

The corn earworm, Heliothis obsoleta (Fab.), a typical cutworm moth, passes through four distinct stages of development: egg, larva (caterpillar), pupa (chrysalis), and adult (moth). The length of time spent in any one stage is influenced by the type of food and by the weather

${ }^{1}$ Received for publication February 14, 1938.

${ }^{2}$ As far as caterpillars attacking tomatoes are concerned, this bulletin supersedes Extension Circular 99, Important Tomato Insects of California, by E. O. Essig and A. E. Michelbacher; certain parts of Circular 99 are quoted. The results of control experiments conducted in 1936 and 1937 have been added.

3 Junior Entomologist in the Experiment Station.

${ }^{4}$ Professor of Entomology and Entomologist in the Experiment Station. 
conditions; in the northern tomato-growing regions of California, there are at least three complete generations of these stages a year. The winter is passed in the pupal stage in earthen cells 2 to 10 inches beneath the soil surface. Emergence of the moths from the overwintering pupae probably occurs principally during the months of May and June.

The adults (fig. 1) have a wing expanse of about $1 \frac{1}{2}$ inches, and their basic color is tan to brownish tan, over which a rather inconspicuous

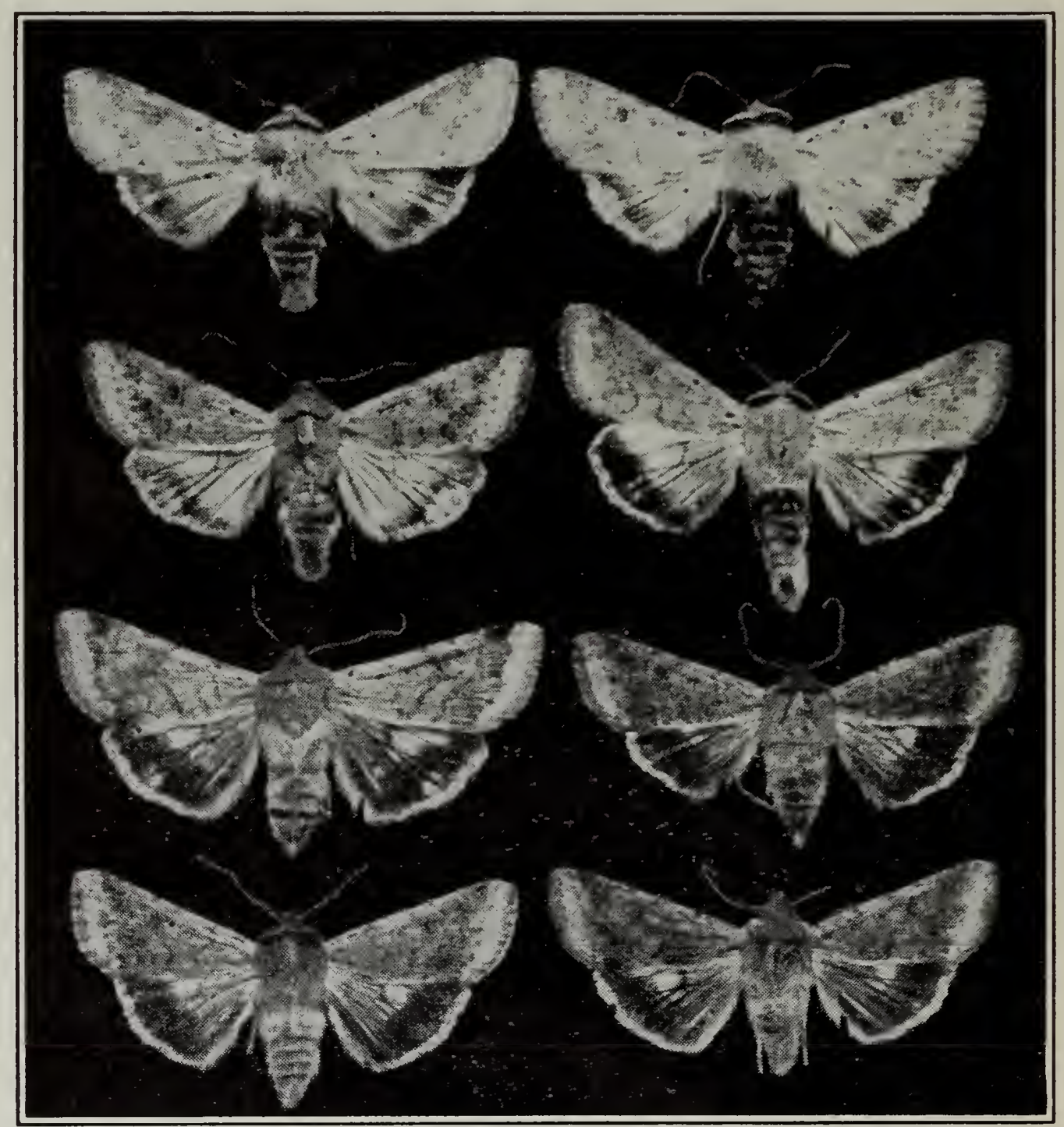

Fig. 1.-Adult moths of the corn earworm, Heliothis obsoleta (Fab.).

but definite darker pattern is superimposed. Egg laying begins several days after emergence and continues until death; a single female may lay 500 to 3,000 eggs throughout the fields. At dusk on warm days in heavily infested tomato fields, female moths may often be seen flitting here and there, seldom flying higher than the tops of the plants, and laying eggs at random over the vines. Only an instant is required for the deposition of an egg. Egg laying usually begins just before dusk and may continue on into the night. 
The eggs (fig. 2, A) are dome-shaped and longitudinally ridged. The color is waxy-white, changing to yellowish. In warm weather they hatch in from 3 to 5 days.

In growing, the larvae, worms, or caterpillars (fig. $2, B$ ) cast their skins about five times, and under favorable conditions may reach maturity in approximately 2 weeks. When full-grown they are about 11/2 inches long, show a marked variation in color from green to almost black, and

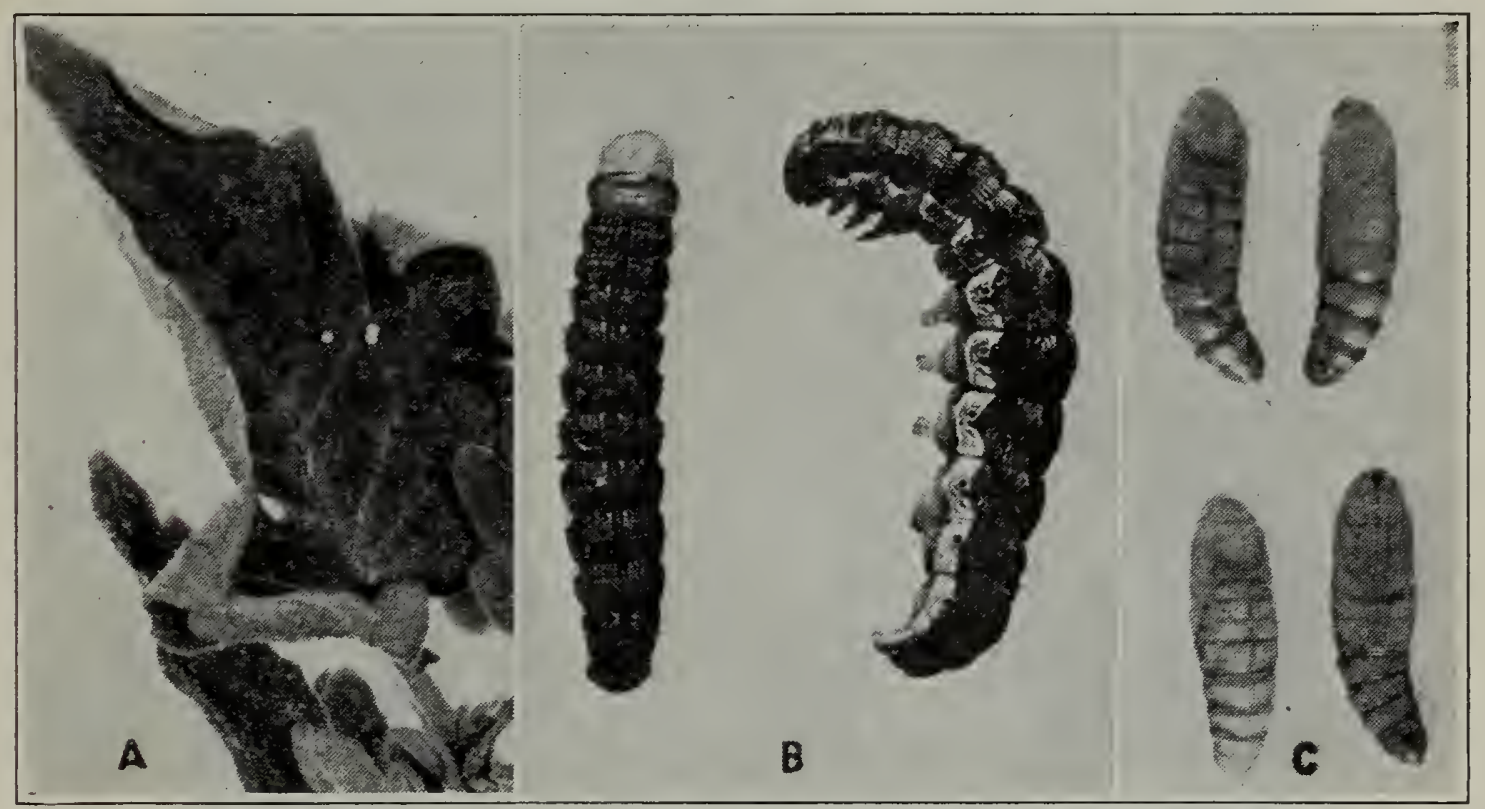

Fig. 2.-The corn earworm, Heliothis obsoleta (Fab.): A, eggs on tomato (courtesy of F. H. Wymore); $B$, full-grown caterpillars; $C$, pupae or chrysalids removed from the soil. (From Ext. Cir. 99.)

may be marked with longitudinal stripes of various colors. They are very cannibalistic and, where two meet in competition or combat, the larger one is usually victorious. On completing development, they burrow into the soil and construct pupal cells a few inches below the surface, from which they build tunnels upwards for the subsequent emergence of the adults. Larvae of the overwintering individuals generally pupate deeper in the soil than those of the summer brood. The chrysalids, or pupae, (fig. $2, C$ ) vary from dark amber to chestnut-brown and are about $3 / 4$ of an inch in length. The duration of the pupal period is only 2 or 3 weeks during the summer but overwinter for the late fall brood. By the first of September, or even before, many of the larvae that pupate are overwintering forms. Some of these may remain in the pupal stage for a year or more.

\section{INSECTS COMMONLY CONFUSED WITH THE CORN EARWORM}

Several other caterpillars are sometimes confused with the corn earworm. Most of these cause very little damage and may be present in fairly large numbers before the corn-earworm infestation occurs. A 
farmer, observing these larvae, and confusing them with the corn earworm, frequently begins control measures against the latter at a time when his efforts will be of little value. These larvae are not always injurious and may be present in fields where the corn earworm would never become a problem and therefore no control would be necessary.

The Alfalfa Looper.-One of the most common of these insects is the alfalfa looper, Autographa californica (Speyer) (fig. 3, B). The cater-

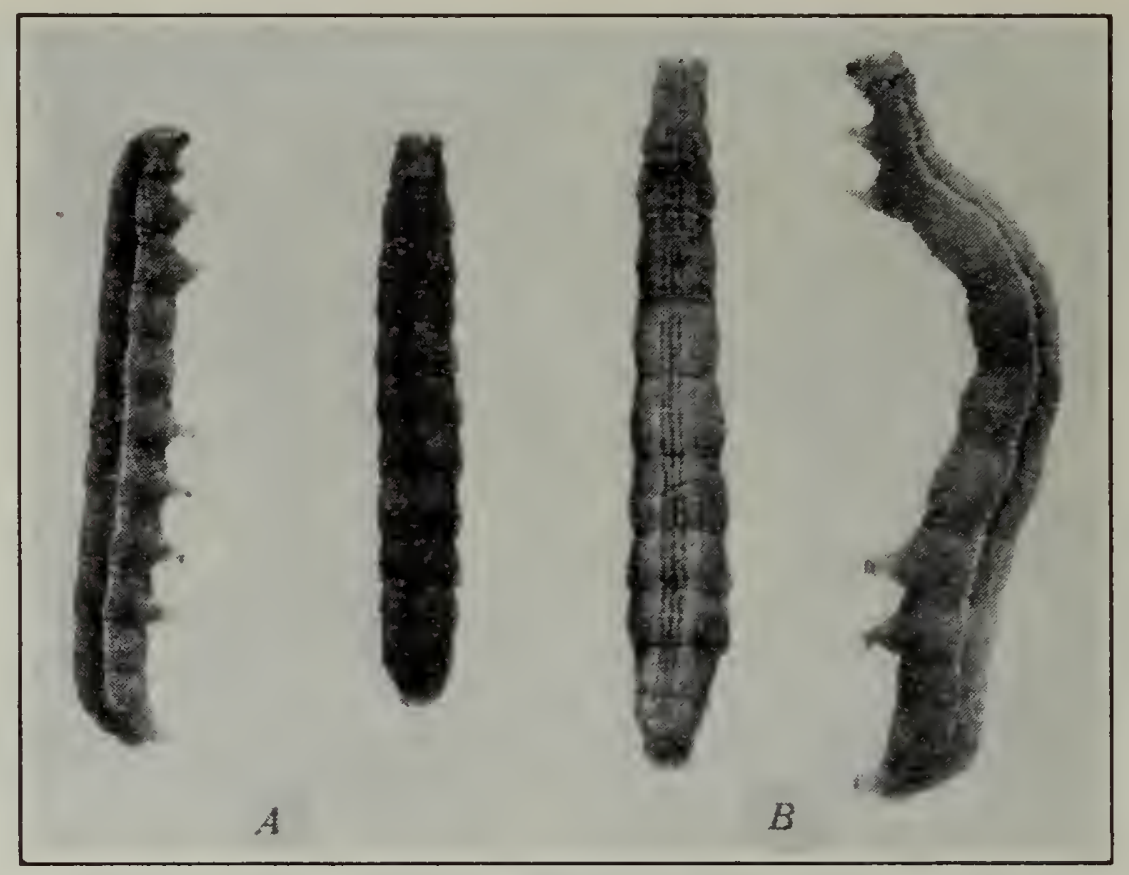

Fig. 3.- $A$, Full-grown larvae of the sugar beet armyworm, Laphygma exigua ( $\mathrm{Hbn}$. ) ; $B$, full-grown larvae of the alfalfa looper, Autographa californica (Speyer).

pillars are green and longitudinally striped with fine whitish lines. In crawling they arch their backs, for which characteristic they are called "loopers." This insect is a foliage feeder; in only a single case was one found feeding on a fruit. They tend to feed towards the center of the tomato vine. In all of our experiences we have never seen them doing sufficient damage to justify control measures.

Sugar Beet Armyworm.-Another very common larva which is mistaken for the corn earworm is the sugar beet armyworm, Laphygma exigua (Hbn.) (fig. 3, A). This larva, sometimes present in tomato fields in large numbers, is usually green in color. It feeds towards the inside of the vine and is mainly a foliage feeder, although it may sometimes attack the fruit. However, very little damage is done to the fruit in comparison with that caused by the corn earworm. Certainly the presence of this insect early in the season would not justify control measures.

Larvae of both of the above-mentioned insects can be distinguished from the corn earworm by the integument, which is rather smooth and 
is nearly free from hairs, while that of the corn earworm is sparsely covered with tubercles which support rather long hairs. Any larvae of these three species can most easily be collected from the tomato plant by shaking a portion of the vine rather vigorously: the worms fall to the ground. A surprisingly large number of loopers and sugar beet army-

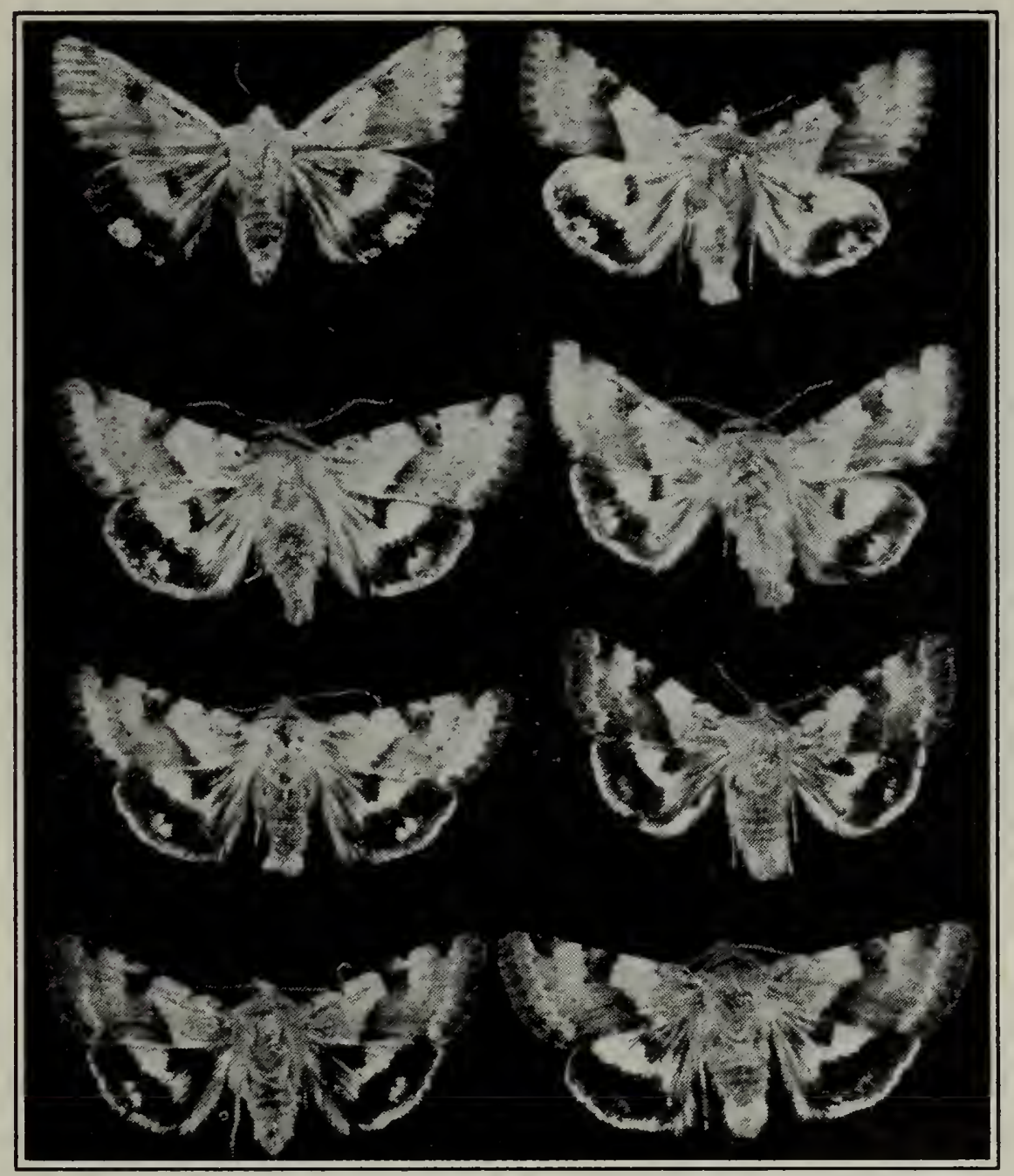

Fig. 4.-Adult moths of Heliothis phloxiphaga (G. and R.)

worms may be recovered from a single vine early in the season, and yet none of the fruit show worm damage.

There are other more-destructive armyworms that might be mistaken for the corn earworm. These are considered under a section on armyworms (p. 22).

Heliothis phloxiphaga.-Heliothis phloxiphaga (Grote and Robinson) is also very likely to be confused with the corn earworm. Early in the growing season, moths of this insect (fig. 4) may be present in large numbers in the tomato fields. The females lay their eggs at random over the tomato vines in much the same manner as does the corn earworm. However, this need cause little concern, for the larva of this insect is unable to develop on either the foliage or the fruit of the tomato. We 
have never reared a single specimen from a tomato fruit. The larvae can develop on such crops as lettuce and alfalfa, but their native hosts are tarweed, Hemizonia congesta, and gum plant, Grindelia camporum. In the late summer and early fall they may be found breeding in large numbers on these hosts. For further details and a rather complete report on these two closely related species see Lange and Michelbacher (1937).

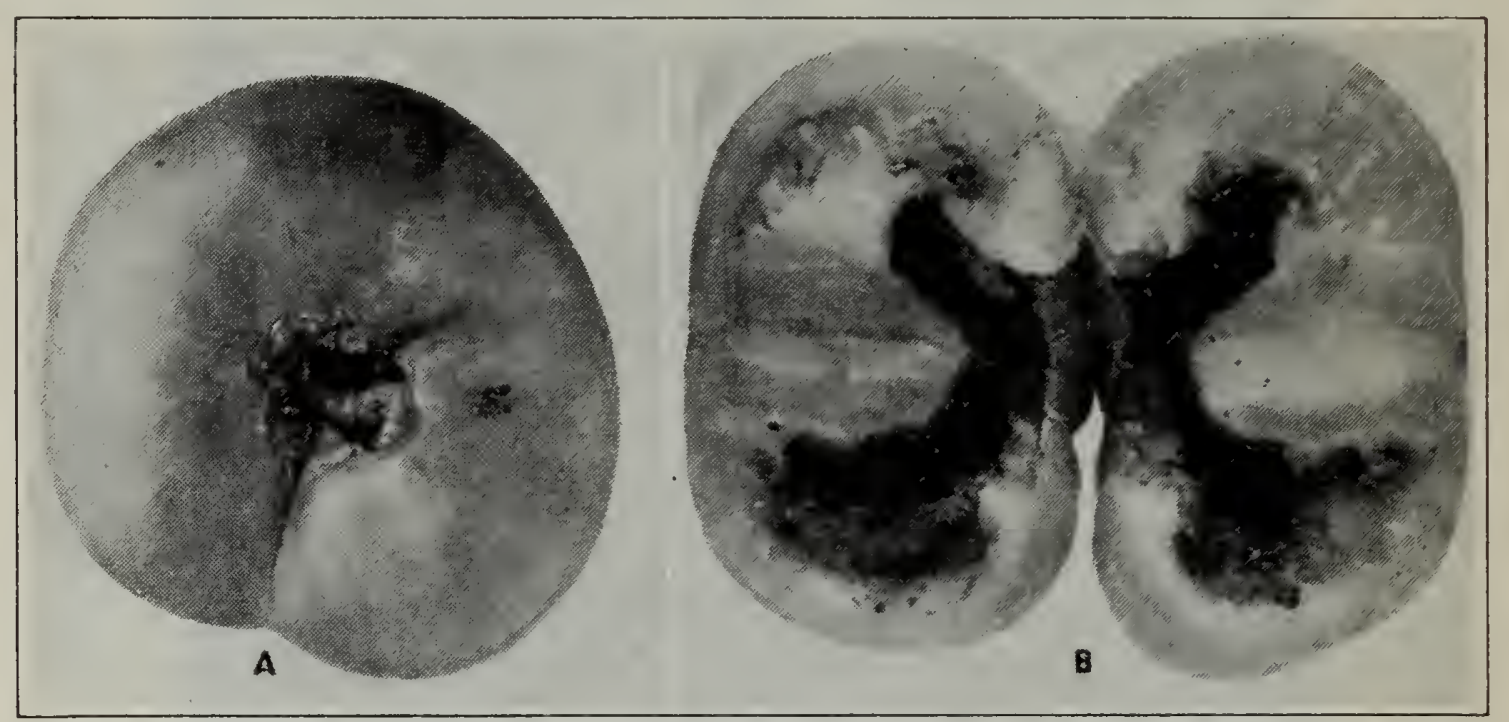

Fig. 5.-Corn-earworm damage to tomatoes: $A$, advanced injury of the calyx, or stem, end with caterpillar in burrow; $B$, tomato cut in half to show the internal destruction caused by the caterpillar. (From Ext. Cir. 99.)

\section{DESTRUCTIVENESS}

The corn earworm ranks as one of the most destructive insects attacking tomatoes. Its serious damage is to the fruit, but it also injures the vine. Where an infestation is severe, more than 50 per cent of the fruit may be destroyed. The moths lay their eggs singly and at random over the periphery of the vine. Most of the eggs are laid on the more recent growth. The newly hatched larvae start feeding on the foliage. If a fruit is not encountered, they may even complete their development on the foliage; in this case they are green in color and the tubercles and hairs do not appear to be as conspicuous as those which develop within the fruit. They apparently do not experience a great deal of trouble in finding the fruit as is evidenced by the fact that many of them enter the fruit at a very early stage of development. Some are so small that it is difficult to detect their entry into the fruit. The larvae usually enter the fruit at the calyx, or stem, end.

Development is usually completed within a single fruit, although a larva may damage or destroy more than one tomato. A nearly mature caterpillar often leaves the fruit in which it has developed and feeds externally on other fruits in the same cluster. Sometimes it even drops to the 
ground and feeds externally on a fruit that is resting on the soil surface. This type of damage is characterized by irregular feeding holes. Late calyx-end injury is shown in figure $5, A$ and $B$, while an earlier stage is shown in figure $6, A$. Sometimes a worm will make several entrance burrows into a fruit without entering it, as illustrated in figure $6, B$.

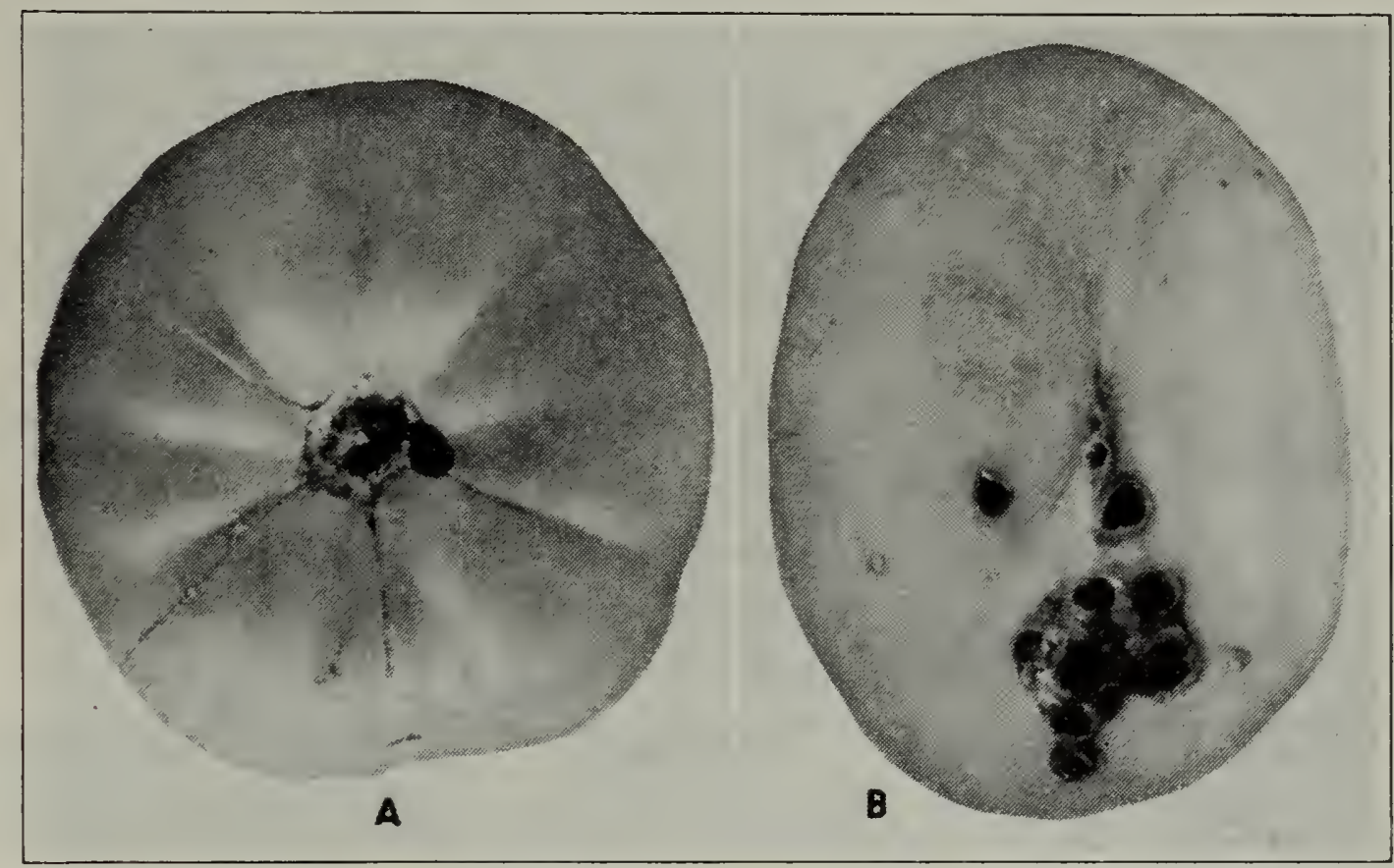

Fig. 6.-Corn-earworn damage to tomatoes: $A$, the calyx removed to show the entrance to the burrow of the caterpillar; $B$, a fruit showing a number of entrances to burrows. (From Ext. Cir. 99.)

\section{HOST RANGE AND HOST PREFERENCE}

The corn earworm has a very extensive host range; it feeds on many different species of wild and cultivated plants. It is an important pest of corn, cotton, tomatoes, tobacco, beans, and several other crops. Apparently sweet corn is the preferred host, although in northern California, caterpillars are present in large numbers on beans and other legumes. Our observations have led us to believe that tomatoes are not a preferred host, but are liable to serious damage because they mature later in the season than most crops and are therefore in an attractive state of growth at a time when other crops are reaching maturity and drying up. Plants that are developing their fruiting bodies and making a rapid growth are probably most attractive to egg-laying moths. This observation has been made by numerous investigators including Bishopp (1922), Thomas and Dunnam (1931), Phillips and Barber (1933), Veitch (1935), Isely (1935), and Barber (1936).

Although tomato plants are set out in the field early in the season, they are rarely subjected to serious attack until August or later, and there are areas where they may go through the entire season without 


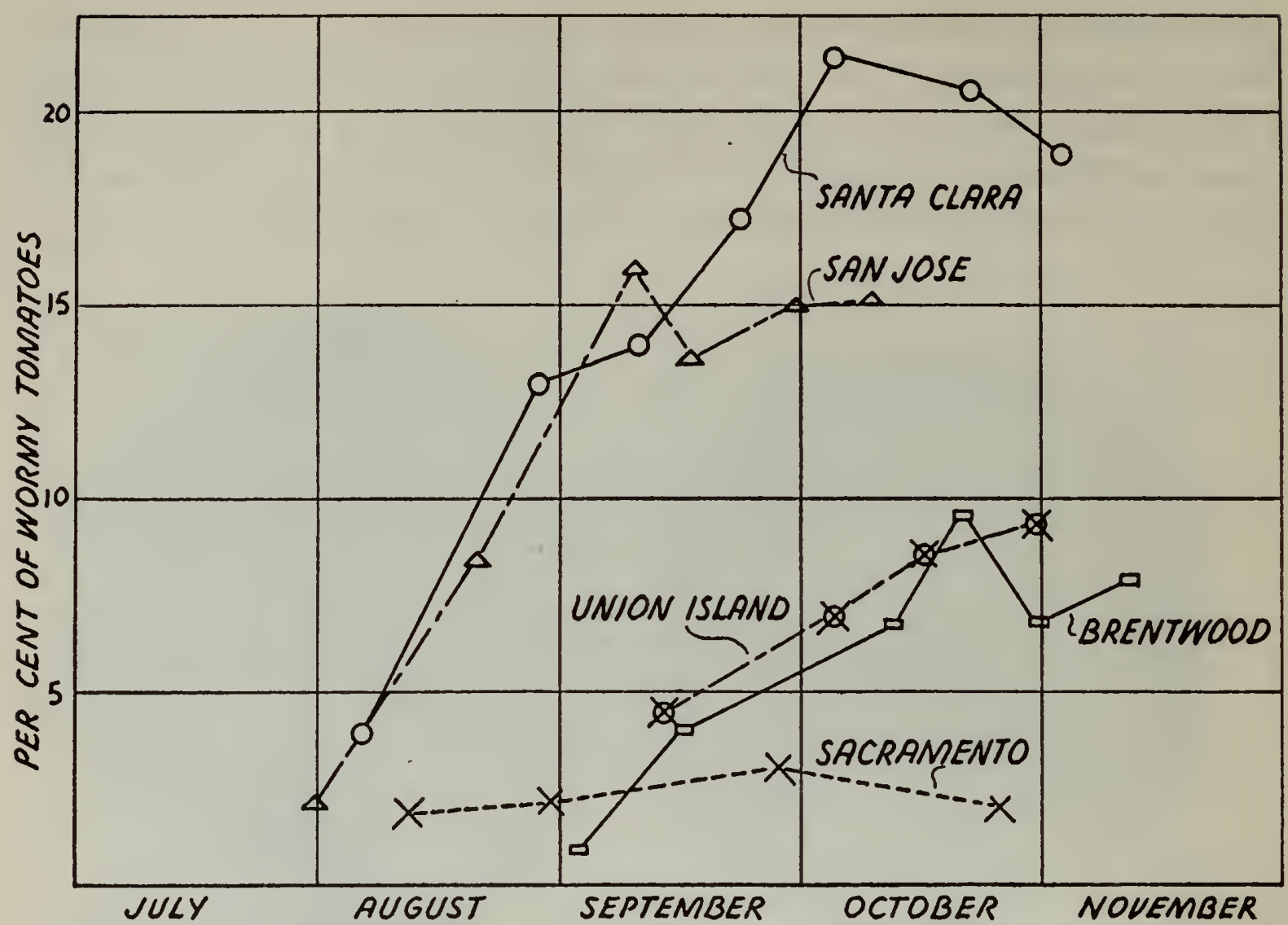

Fig. 7.- Infestation trends of the corn earworm for 1936 in check plots associated with experimental series located at several points in the northern tomato-growing region of California.

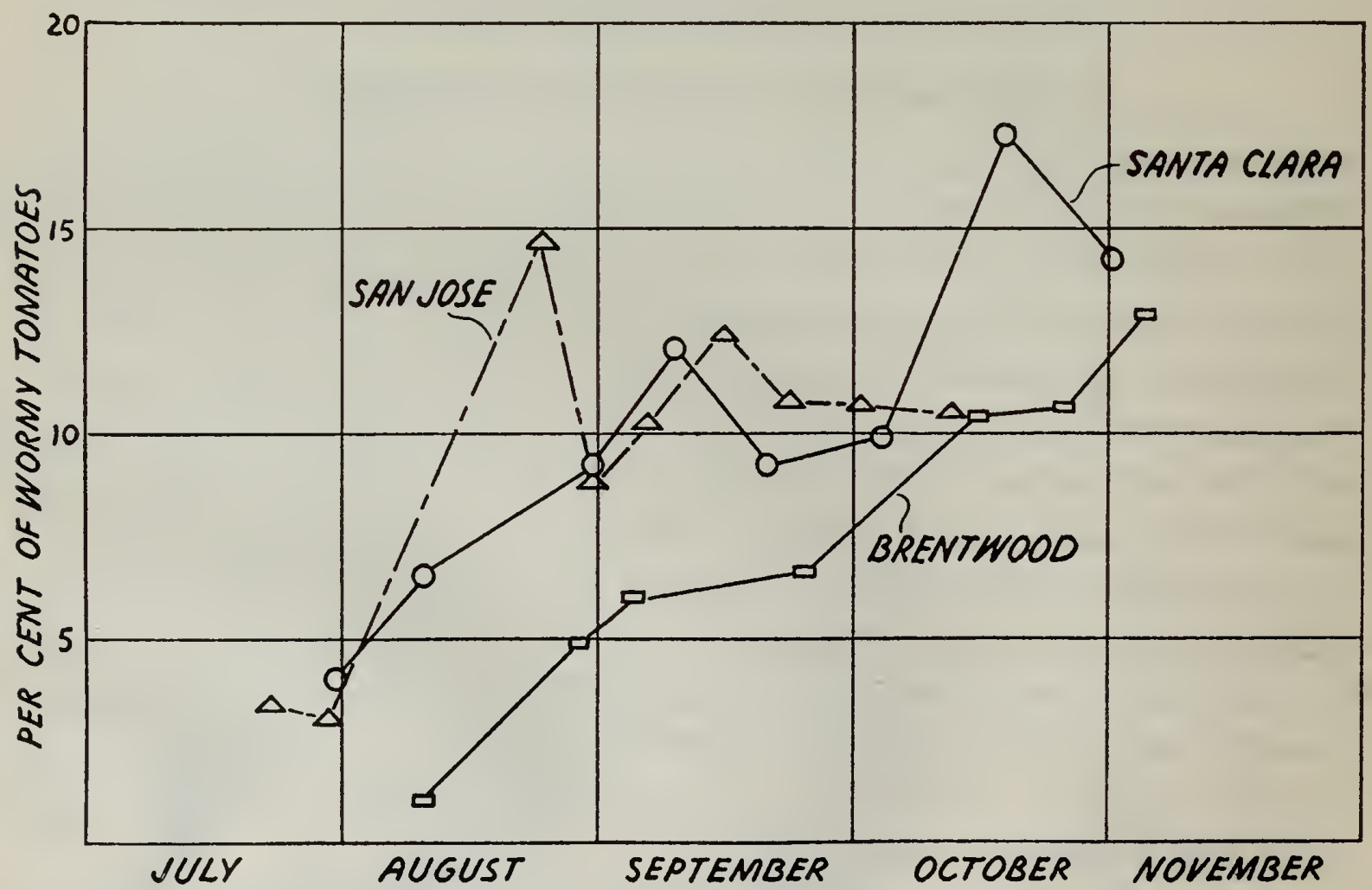

Fig. 8.- Infestation trends of the corn earworm for 1937 in check plots associated with experimental series at San Jose, Santa Clara, and Brentwood. The curve for Brentwood includes both worm-infested and worm-stung fruit, the other two worminfested fruit. 
being seriously infested. The reason for this seems to be linked with host sequence or types of crops grown in the various sections. The overwintering moths may start emerging as early as May, and by the end of June sweet corn may be severely infested. During July nearly all ears of sweet corn may be attacked, while tomatoes growing only a short distance away may show a very low infestation. Beans also appear to attract egg-laying moths to a greater extent than tomatoes, and in some sections there is a considerable build-up on this crop, as on corn. Isely (1935) made some very interesting observations along these lines and found that a combination of corn and leguminous crops may lead to a serious outbreak on cotton. He also reported that the larvae develop slowly on the fruit and leaves of tomato.

During the past two seasons we encountered no serious infestation before the first of August. Figures 7 and 8 show the trend of the infestation for several regions based on the amount of worminess observed in the check plots connected with our various experimental areas. In the area about San Jose and Santa Clara, the infestation reaches serious proportions by about August 15, probably because the moth population, which builds up on the corn crop, has in part moved into the tomato fields. By the end of July there is very little corn left standing that would be attractive to the corn-earworm moths, and thus there must be a heavy migration away from most corn fields into the tomato patches. In the Brentwood and Union Island areas, the infestation set in rather late, and was just beginning to be noticeable by September 1 . The infestation in this area probably arises from a build-up on a crop such as beans. Baby-lima-bean fields were examined on the west side of the San Joaquin Valley in 1937 : during the first part of August, corn-earworm larvae could be found rather easily, but by the end of August most of these fields were apparently not very attractive to the moths; in fact, by the first of September, when harvest was well under way, there must have been a heavy moth emergence and migration from these fields to tomatoes, alfalfa, and a scattering of truck crops, such as lettuce, which were the only crops attractive to egg-laying adults at that season. Our records for the past three years have shown a marked increase in the corn-earworm population in tomato fields late in the season throughout this area. If an infestation once becomes established in a locality, it is likely to continue for the remainder of the season. If it begins in August, there is apparently sufficient time for two generations of larvae in the field before harvest is completed. 


\section{CHEMICAL CONTROL}

Previous Work with Arsenicals.-A large number of insecticides have been used against the corn earworm on tomatoes. Lead arsenate has been recommended by Watson (1912), Bishopp (1922), Davis, Spencer, and Zimmerley (1924), Edwards (1935), Knowlton and Smith (1935), Sherman (1935), Houser (1936), Bailey (1936), and Morgan and Hely (1936). Control with calcium arsenate is reported by Bishopp (1922), Davis, Spencer, and Zimmerley (1924), Morrill (1926), and Knowlton and Smith (1935). In some cases the insecticides were used in combination

\begin{tabular}{|c|c|c|c|c|c|}
\hline CHECK & $\begin{array}{c}\text { BARIUM } \\
\text { FLUOSILICATE }\end{array}$ & $\begin{array}{c}\text { LEARO } \\
\text { ARSENATE }\end{array}$ & $\begin{array}{c}\text { SODIUM } \\
\text { FLUOSILICATE }\end{array}$ & $\begin{array}{c}\text { CALCIUM } \\
\text { ARSENATE }\end{array}$ & CRYOLITE \\
\hline \hline CRYOLITE & $\begin{array}{c}\text { SODIUM } \\
\text { FLUOSILICATE }\end{array}$ & $\begin{array}{c}\text { CALCIUM } \\
\text { ARSENATE }\end{array}$ & CHECK & $\begin{array}{c}\text { BARIUM } \\
\text { FLUOSILICATE }\end{array}$ & $\begin{array}{c}\text { LEAD } \\
\text { ARSENATE }\end{array}$ \\
\hline $\begin{array}{c}\text { LEAD } \\
\text { ARSENATE }\end{array}$ & CHECK & $\begin{array}{c}\text { BARIUM } \\
\text { FLUOSILICATE }\end{array}$ & CRYOLITE & $\begin{array}{c}\text { SODIUM } \\
\text { FLUOSILICATE }\end{array}$ & $\begin{array}{c}\text { CALCIUM } \\
\text { ARSENATE }\end{array}$ \\
\hline \hline $\begin{array}{l}\text { CALCIUM } \\
\text { ARSENATE }\end{array}$ & CRYOLITE & $\begin{array}{c}\text { SODIUM } \\
\text { FLUOSILICATE }\end{array}$ & ARSENATE & CHECK & $\begin{array}{c}\text { BARIUM } \\
\text { FLUSILICATE }\end{array}$ \\
\hline
\end{tabular}

Fig. 9.-Plot arrangement used in the 1936 tomato investigations.

with fungicides, but thus far in our investigations we have not encountered conditions indicating that the addition of a fungicide would be of any value.

Experimental Work with Calcium Arsenate, Lead Arsenate, Cryolite, Barium Fluosilicate, and Sodium Fluosilicate.-In 1936 the following standard insecticidal dusts were used experimentally : undiluted commercial calcium arsenate, 50 per cent lead arsenate in talc, 40 per cent synthetic cryolite in soapstone, 40 per cent barium fluosilicate in soapstone, and a 40 per cent sodium fluosilicate in aluminum silicate. When the vines were large the fluosilicates were applied at the rate of 30 pounds to the acre, lead arsenate at the rate of 20 pounds per acre, and calcium arsenate at the rate of 15 pounds per acre.

Because tomatoes are grown in areas having different climates, experimental series were located at San Jose (table 1), Santa Clara (table 2), Brentwood (table 3), Union Island (table 4), and near Sacramento (table 5). At each location all of the five treatments were replicated four times, so that including the checks, each experimental series was composed of 24 plots. A random distribution of plots was used. Figure 9 


\section{TABLE 1}

San Jose Corn-Earworm-Control Experiments with Cryolite, Fluosilicate, and Arsenate Dusts

(Plots dusted August 3 and August 27, 1936)

\begin{tabular}{|c|c|c|c|c|c|c|}
\hline \multicolumn{2}{|l|}{ Treatment } & \multicolumn{5}{|c|}{ Per cent of wormy tomatoes } \\
\hline Material & $\begin{array}{c}\text { Pounds } \\
\text { per acre }\end{array} \mid$ & $\begin{array}{l}\text { August 21, } \\
\text { prior to } \\
\text { first } \\
\text { picking }\end{array}$ & $\begin{array}{l}\text { September } \\
10, \text { prior to } \\
\text { third } \\
\text { picking }\end{array}$ & $\begin{array}{l}\text { September } \\
17 \text {, prior to } \\
\text { fourth } \\
\text { picking }\end{array}$ & $\begin{array}{c}\text { September } \\
29, \text { prior to } \\
\text { ffth } \\
\text { picking }\end{array}$ & $\begin{array}{l}\text { October } 9, \\
\text { prior to } \\
\text { sixth } \\
\text { picking }\end{array}$ \\
\hline Check. & 0 & 8.56 & 15.93 & 13.56 & 14.94 & 15.18 \\
\hline 40 per cent cryolite. . & 30 & 4.43 & 4.43 & 5.25 & 3.56 & 4.25 \\
\hline 40 per cent barium fluosilicate. & 30 & 3.93 & 3.43 & 3.50 & 3.68 & 5.18 \\
\hline 40 per cent sodium fluosilicate. & 30 & 6.62 & 10.56 & 11.00 & 8.56 & 10.93 \\
\hline $\begin{array}{l}\text { Straight commercial calcium } \\
\text { arsenate } \ldots \ldots \ldots \ldots \ldots \ldots \ldots\end{array}$ & 15 & 3.18 & 3.81 & 3.62 & 2.19 & 4.12 \\
\hline 50 per cent lead arsenate........ & 20 & 4.56 & 3.62 & 3.31 & 3.44 & 3.93 \\
\hline
\end{tabular}

TABLE 2

Santa Clara Corn-Earworn-Control Experiments with Cryolite, Fluosilicate, and Arsenate Dusts

(Plots dusted August 7, 29, and September 26, 1936)

\begin{tabular}{|c|c|c|c|c|c|c|c|}
\hline \multicolumn{2}{|l|}{ Treatment } & \multicolumn{6}{|c|}{ Percentage of wormy tomatoes } \\
\hline Material & $\begin{array}{l}\text { Pounds } \\
\text { per acre }\end{array}$ & $\begin{array}{c}\text { August 27, } \\
\text { prior to a } \\
\text { very light } \\
\text { picking }\end{array}$ & $\begin{array}{l}\text { September } \\
11 \text {, prior to } \\
\text { first major } \\
\text { picking }\end{array}$ & $\begin{array}{l}\text { September } \\
23, \text { prior to } \\
\text { second } \\
\text { picking }\end{array}$ & $\begin{array}{l}\text { October 5, } \\
\text { prior to } \\
\text { third } \\
\text { picking }\end{array}$ & \begin{tabular}{|} 
October 22, \\
prior to \\
fourth \\
picking
\end{tabular} & $\begin{array}{l}\text { November } \\
3 \text {, prior to } \\
\text { fifth } \\
\text { picking }\end{array}$ \\
\hline Check. & 0 & 13.1 & 14.1 & 17.7 & 21.4 & 20.4 & 18.9 \\
\hline 40 per cent cryolite..... & 30 & 8.3 & 5.1 & 6.5 & 5.5 & 5.5 & 5.2 \\
\hline $\begin{array}{l}40 \text { per cent barium fluo- } \\
\text { silicate............... }\end{array}$ & 30 & 5.9 & 3.7 & 4.6 & 4.4 & 6.5 & 4.9 \\
\hline $\begin{array}{l}40 \text { per cent sodium fluo- } \\
\text { silicate.............. }\end{array}$ & 30 & 9.2 & 8.7 & 10.0 & 12.1 & 12.7 & 12.0 \\
\hline $\begin{array}{l}\text { Straight commercial cal- } \\
\text { cium arsenate........ }\end{array}$ & 15 & 6.6 & 4.6 & 5.7 & 4.7 & 4.4 & 3.4 \\
\hline 50 per cent lead arsenate. & 20 & 6.6 & 3.2 & 4.0 & 4.2 & 4.4 & 4.2 \\
\hline
\end{tabular}

shows the arrangement used in each of the experimental series. All materials were applied with hand dusters. The size of the individual plots in the different experimental series was as follows: San Jose, 0.75 acre; Santa Clara, 0.45 acre; Brentwood, 0.75 acre; Union Island, 0.63 acre; and Sacramento, 0.48 acre.

At various times during the harvest, the amount of infested fruit in the different plots was determined, usually prior to picking, and in each plot at least 400 fruits were examined. The information obtained is summarized by areas in tables 1 to 5 inclusive. It should be noted that the 


\section{TABLE 3}

Brentwood Corn-Earworm-Control Experiments with Cryolite, Fuuosilicate, and Arsenate Dusts

(Plots dusted only once September 16, 1936*)

\begin{tabular}{|c|c|c|c|c|c|c|c|}
\hline \multicolumn{2}{|l|}{ Treatment } & \multicolumn{6}{|c|}{ Per cent of wormy tomatoes } \\
\hline \multirow{2}{*}{ Material } & \multirow{2}{*}{$\begin{array}{l}\text { Pounds } \\
\text { per acre }\end{array}$} & \multirow{2}{*}{$\begin{array}{l}\text { October } 12, \\
\text { prior to } \\
\text { first } \\
\text { picking } \dagger\end{array}$} & \multirow{2}{*}{$\begin{array}{l}\text { October 21, } \\
\text { prior to } \\
\text { second } \\
\text { pickingt }\end{array}$} & \multicolumn{2}{|c|}{$\begin{array}{l}\text { Prior to third } \\
\text { picking }\end{array}$} & \multicolumn{2}{|c|}{$\begin{array}{l}\text { November } 11 \text {, prior } \\
\text { to fourth picking }\end{array}$} \\
\hline & & & & Wormy & Stings $\ddagger$ & Wormy & Stings ${ }_{4}^{*}$ \\
\hline Check. . & 0 & 6.73 & 9.39 & 6.69 & 6.91 & 7.69 & 8.21 \\
\hline 40 per cent cryolite. & 30 & 4.08 & 5.08 & 4.20 & 5.47 & 4.19 & 6.13 \\
\hline 40 per cent barium fluosilicate & 30 & 2.03 & 3.14 & 3.24 & 4.51 & 3.14 & 6.30 \\
\hline 40 per cent sodium fluosilicate & 30 & 3.53 & 6.38 & 6.90 & 7.91 & 6.30 & 8.88 \\
\hline Commercial calcium arsenate & 15 & 2.12 & 3.46 & 2.37 & 2.48 & 1.80 & 2.14 \\
\hline 50 per cent lead arsenate.... & 20 & 2.40 & 2.91 & 2.66 & 1.98 & 2.34 & 2.88 \\
\hline
\end{tabular}

* Shipping variety and harvested green for eastern shipment.

$\dagger$ No records made of stings or superficially injured fruit.

$\ddagger$ Includes superficially injured fruit.

\section{TABLE 4}

Union Island Corn-Earworm-Control Experiments with Cryolite, Fiuosilicate, and A rsenate Dusts

(Plots dusted July 17, August 24, and September 25, 1936*)

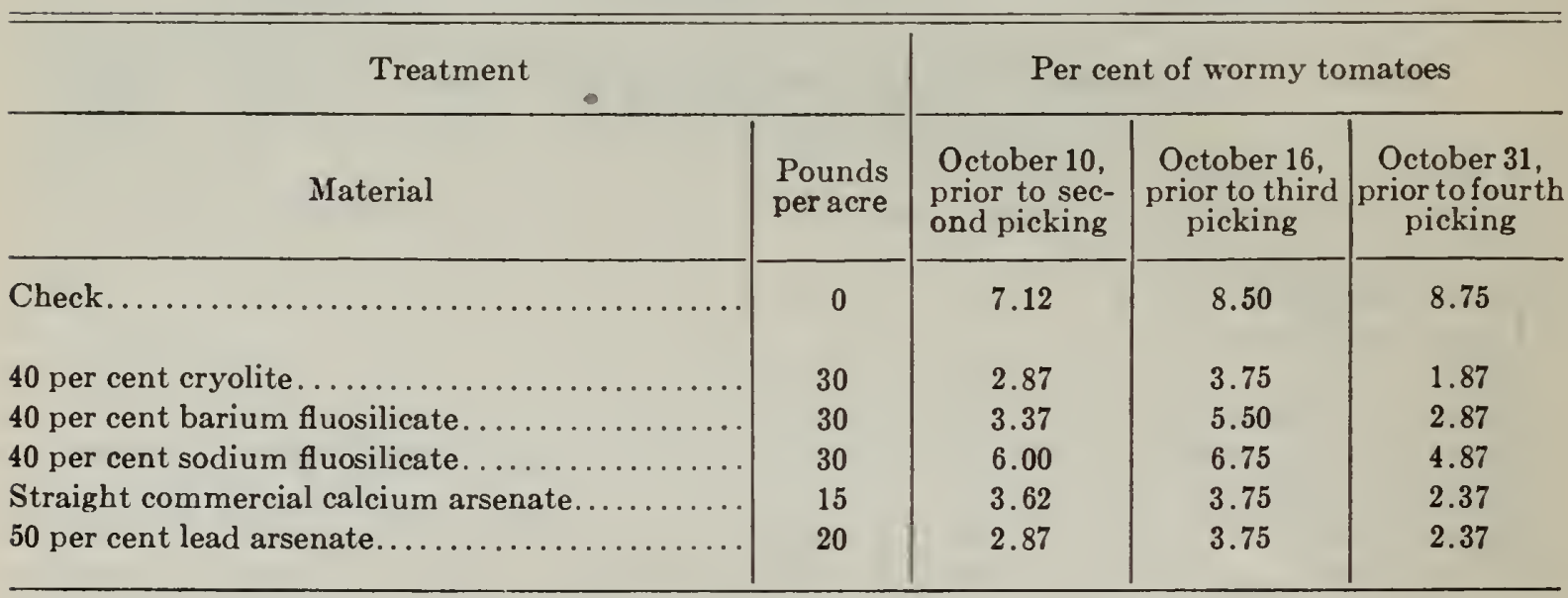

* The first two dustings were directed against hornworms; the corn earworm did not make its appearance until after the first of September.

results in the various experimental series tend to substantiate one another. Calcium arsenate, lead arsenate, cryolite, and barium fluosilicate gave good control. While sodium fluosilicate gave results not nearly so good as were obtained with the other materials, it should be pointed out that only a 40 per cent dust was used whereas the manufacturer's recommendations call for a 70 per cent dust. A 40 per cent dust was used in this investigation because we wished to determine the effectiveness of the various fluosilicates at this strength. The results show that success- 
ful control can be obtained by spacing the dustings 3 to 4 weeks apart, and that not more than three applications should be necessary to control the pest successfully throughout the entire season. Furthermore, calcium arsenate is evidently as effective as lead arsenate. This should result in the elimination of lead arsenate as an insecticide for control of the corn earworm, because it contains two elements, arsenic and lead, on which there is a legal tolerance.

On the whole, the arsenicals appear to give better control than did the fluosilicates. Too much significance should not be attached to this fact,

\section{TABLE 5}

Sacramento Corn-Earworm-Control Experiments with Cryolite, Fluosilicate, and Arsenate Dusts

(Plots dusted August 12 and September 5, 1936)

\begin{tabular}{|c|c|c|c|c|}
\hline \multicolumn{2}{|l|}{ Treatment } & \multicolumn{3}{|c|}{ Per cent of wormy tomatoes } \\
\hline Material & $\begin{array}{l}\text { Pounds } \\
\text { per acre }\end{array}$ & $\begin{array}{l}\text { August } 30, \\
\text { prior to sec- } \\
\text { ond picking }\end{array}$ & $\begin{array}{l}\text { September 27. } \\
\text { prior to fifth } \\
\text { picking }\end{array}$ & $\begin{array}{l}\text { October } 26 \text {, } \\
\text { prior to sev- } \\
\text { enth picking }\end{array}$ \\
\hline Check. & 0 & 2.12 & 3.00 & 2.00 \\
\hline 40 per cent cryolite. & 30 & 2.18 & 1.06 & 0.75 \\
\hline 40 per cent barium fluosilicate. & 30 & 1.68 & 1.06 & 0.56 \\
\hline 40 per cent sodium fluosilicate............... & 30 & 1.93 & 1.56 & 1.87 \\
\hline Straight commercial calcium arsenate.......... & 15 & 1.12 & 0.87 & 0.37 \\
\hline 50 per cent lead arsenate.............. & 20 & 1.18 & 0.81 & 0.56 \\
\hline
\end{tabular}

however, because different brands of the same insecticide probably vary in effectiveness, and possibly if different brands had been used, one or both of the fluosilicates might have proved slightly better than the arsenicals.

None of the insecticides used caused any apparent burning.

Experimental Work with Phenothiazine, Kutane, and Calcium Arsenate.-During 1936 some experiments were also conducted with insecticides less toxic to man than those discussed above. These included 15 per cent phenothiazine with 85 per cent talc as a carrier, and 24 per cent Kutane with 76 per cent talc as a carrier. (Kutane consists of cuprous cyanide 84 per cent, and a wetting and spreading agent, principally Goulac, 16 per cent.) These materials were used at the rate of 30 pounds to the acre on 0.1 acre plots and replicated four times. Because they showed considerable promise in 1936, they were used on a larger scale in 1937 and their effectiveness was checked against calcium arsenate. Experimental series were established at San Jose (table 6), Santa Clara (table 7), and at Brentwood (table 8). At each location every treatment 
was replicated four times, so that, including the checks, each series contained 16 plots each 0.40 acre in size. The arrangement of the plots for each of the series is shown in figure 10.

The effectiveness of these materials was measured in the same way as in 1936, and is reported by areas in tables 6 to 8 . Neither phenothiazine

\begin{tabular}{|c|c|c|c|}
\hline CHECK & $\begin{array}{c}\text { CALCIUM } \\
\text { ARSENATE }\end{array}$ & PHENOTHIAZINE & KUTANE \\
\hline \hline PHENOTHIAZINE & KUTANE & CHECK & $\begin{array}{c}\text { CALCIUM } \\
\text { ARSENATE }\end{array}$ \\
\hline \hline $\begin{array}{l}\text { CALCIUM } \\
\text { ARSENATE }\end{array}$ & CHECK & KUTANE & PHENOTHIAZINE \\
\hline \hline KUTANE & PHENOTHIAZINE & $\begin{array}{c}\text { CALCIUM } \\
\text { ARSENATE }\end{array}$ & CHECK \\
\hline
\end{tabular}

Fig. 10.-Plot arrangement used in the 1937 tomato investigations.

nor Kutane proved to be so effective as calcium arsenate. Calcium arsenate (same brand and lot as used in 1936) proved to be very effective, and substantiated the results of the preceding year. The work again showed that even in the most wormy areas not more than three applications of an insecticide are necessary for successful control.

\section{TABLE 6}

San Jose Corn-Earworm-Control Experiments with Calcium Arsenate, Phenothiazine, and Cuprous Cyanide

(Plots dusted August 2 and August 27, 1937)

\begin{tabular}{|c|c|c|c|c|c|c|c|c|}
\hline \multicolumn{2}{|l|}{ Treatment } & \multicolumn{7}{|c|}{ Per cent of wormy tomatoes } \\
\hline Material & $\begin{array}{l}\text { Pounds } \\
\text { per acre }\end{array}$ & $\begin{array}{c}\text { August } 23 \\
\text { prior to } \\
\text { first } \\
\text { picking }\end{array}$ & $\begin{array}{l}\text { August31. } \\
\text { prior to } \\
\text { second } \\
\text { picking }\end{array}$ & $\begin{array}{l}\text { Septem- } \\
\text { ber } 6 \text {, } \\
\text { prior to } \\
\text { third } \\
\text { picking }\end{array}$ & $\begin{array}{l}\text { Septem- } \\
\text { ber } 15 \text {, } \\
\text { prior to } \\
\text { fourth } \\
\text { picking }\end{array}$ & $\begin{array}{l}\text { Septem- } \\
\text { ber } 22, \\
\text { prior to } \\
\text { fifth } \\
\text { picking }\end{array}$ & $\begin{array}{l}\text { October } \\
1, \\
\text { prior to } \\
\text { sixth } \\
\text { picking }\end{array}$ & $\begin{array}{l}\text { October } \\
11, \\
\text { prior to } \\
\text { seventh } \\
\text { picking }\end{array}$ \\
\hline Check. & 0 & 14.68 & 8.75 & 10.12 & 12.31 & 10.62 & 10.50 & 10.31 \\
\hline $\begin{array}{c}\text { Straight commercial } \\
\text { calcium arsenate. }\end{array}$ & 15 & 5.37 & 2.56 & 1.25 & 1.18 & 2.43 & 1.31 & 1.62 \\
\hline $\begin{array}{l}15 \text { per cent pheno- } \\
\text { thiazine............ }\end{array}$ & 30 & 5.31 & 3.56 & 3.62 & 4.68 & 4.75 & 3.43 & 3.75 \\
\hline 24 per cent Kutane* & 30 & 8.00 & 3.87 & 3.93 & 4.43 & 5.00 & 4.06 & 3.43 \\
\hline
\end{tabular}

* Cuprous cyanide 84 per cent, wetting and spreading agent (principally Goulac) 16 per cent. This material was mixed with talc at the rate of 24 pounds of Kutane to 76 pounds of talc. 


\section{TABLE 7}

Santa Clara Corn-Earworm-Control Experiments with Calcium Arsenate, Phenothiazine, and Cuprous Cyanide

(Plots dusted August 9, September 2, and October 1, 1937)

\begin{tabular}{|c|c|c|c|c|c|c|}
\hline \multicolumn{2}{|l|}{ Treatment } & \multicolumn{5}{|c|}{ Per cent of wormy tomatoes } \\
\hline Material & $\left|\begin{array}{l}\text { Pounds } \\
\text { per acre }\end{array}\right|$ & $\begin{array}{l}\text { September } \\
10 \text {, prior to } \\
\text { first } \\
\text { picking }\end{array}$ & $\begin{array}{l}\text { September } \\
20 \text {, prior to } \\
\text { second } \\
\text { picking }\end{array}$ & $\begin{array}{c}\text { October } 4, \\
\text { prior to } \\
\text { third } \\
\text { picking }\end{array}$ & $\begin{array}{l}\text { October } 18, \\
\text { prior to } \\
\text { fourth } \\
\text { picking }\end{array}$ & $\begin{array}{l}\text { November } \\
\text { 1, prior to } \\
\text { fifth } \\
\text { picking }\end{array}$ \\
\hline Check. & 0 & 12.06 & 9.12 & 9.93 & 17.25 & 14.25 \\
\hline $\begin{array}{l}\text { Straight commercial calcium } \\
\text { arsenate } \ldots \ldots \ldots \ldots \ldots \ldots\end{array}$ & 15 & 4.87 & 1.75 & 1.68 & 3.43 & 4.00 \\
\hline 15 per cent phenothiazine... & 30 & 7.37 & 3.50 & 4.00 & 10.81 & 6.87 \\
\hline 24 per cent Kutane* & 30 & 7.75 & 4.18 & 4.68 & 8.56 & 7.00 \\
\hline
\end{tabular}

* Cuprous cyanide 84 per cent, wetting and spreading agent (principally Goulac) 16 per cent. This material was mixed with talc at the rate of 24 pounds of Kutane to 76 pounds of talc.

\section{TABLE 8}

Brentwood Corn-Earworm-Control Experinents with Calcium Arsenate, Phenothiazine, and Cuprous Cyanide

(Plots dusted August 28, and September 24, 1937*)

\begin{tabular}{|c|c|c|c|c|c|c|c|c|c|}
\hline \multicolumn{2}{|l|}{ Treatment } & \multicolumn{8}{|c|}{ Per cent of wormy tomatoes } \\
\hline \multirow{2}{*}{ Material } & \multirow{2}{*}{$\begin{array}{l}\text { Pounds } \\
\text { per acre }\end{array}$} & \multicolumn{2}{|c|}{$\begin{array}{c}\text { September } 29 \\
\text { prior to } \\
\text { first picking }\end{array}$} & \multicolumn{2}{|c|}{$\begin{array}{l}\text { October } 15, \\
\text { prior to } \\
\text { second picking }\end{array}$} & \multicolumn{2}{|c|}{$\begin{array}{l}\text { October } 25, \\
\text { prior to } \\
\text { third picking }\end{array}$} & \multicolumn{2}{|c|}{$\begin{array}{l}\text { November } 5 \text {, } \\
\text { prior to } \\
\text { fourth picking }\end{array}$} \\
\hline & & Wormy & Stings $†$ & Wormy & Stings $†$ & Wormy & Stings $†$ & Wormy & Stings $\dagger$ \\
\hline Check. & 0 & 2.33 & 2.27 & 3.53 & 3.67 & 2.10 & 5.90 & 4.13 & 8.84 \\
\hline $\begin{array}{l}\text { Straight commercial cal- } \\
\quad \text { cium arsenate } \ldots \ldots \ldots\end{array}$ & 15 & 0.85 & 0.54 & 0.89 & 0.67 & 1.00 & 0.86 & 1.29 & 2.46 \\
\hline 15 per cent phenothiazine. & 30 & 1.22 & 1.04 & 1.62 & 2.61 & 1.13 & 2.37 & 3.38 & 5.64 \\
\hline 24 per cent Kutane $ł . . . .$. & 30 & 1.19 & 1.06 & 1.73 & 1.50 & 0.98 & 1.38 & 1.61 & 3.27 \\
\hline
\end{tabular}

* Shipping variety harvested green for eastern shipment.

$\dagger$ Includes superficially injured fruit.

† Cuprous cyanide 84 per cent, and wetting and spreading agent (principally Goulac) 16 per cent. This material was mixed with talc at the rate of 24 pounds of Kutane to 76 pounds of talc.

Experimental Work with Pyrethrum, Derris, and Epsom Salts.-During the 1937 season, some experimental work was done with 40 per cent pyrethrum ( 0.2 per cent pyrethrins) in sulfur, derris (sulfur 80 per cent, rotenone 0.75 per cent), powdered Epsom salts (Epsom salts 30 per cent, cocoanut oil 13 per cent, inert material 57 per cent). These materials, replicated twice, were applied to plots approximately 0.1 acre in area and were placed along the edge of the experimental series located at San 
TABLE 9

San Jose Corn-Earworm-Control Experiments with Pyrethrum, Derris, And Epsom Salts

(Plots dusted August 10 and August 27, 1937)

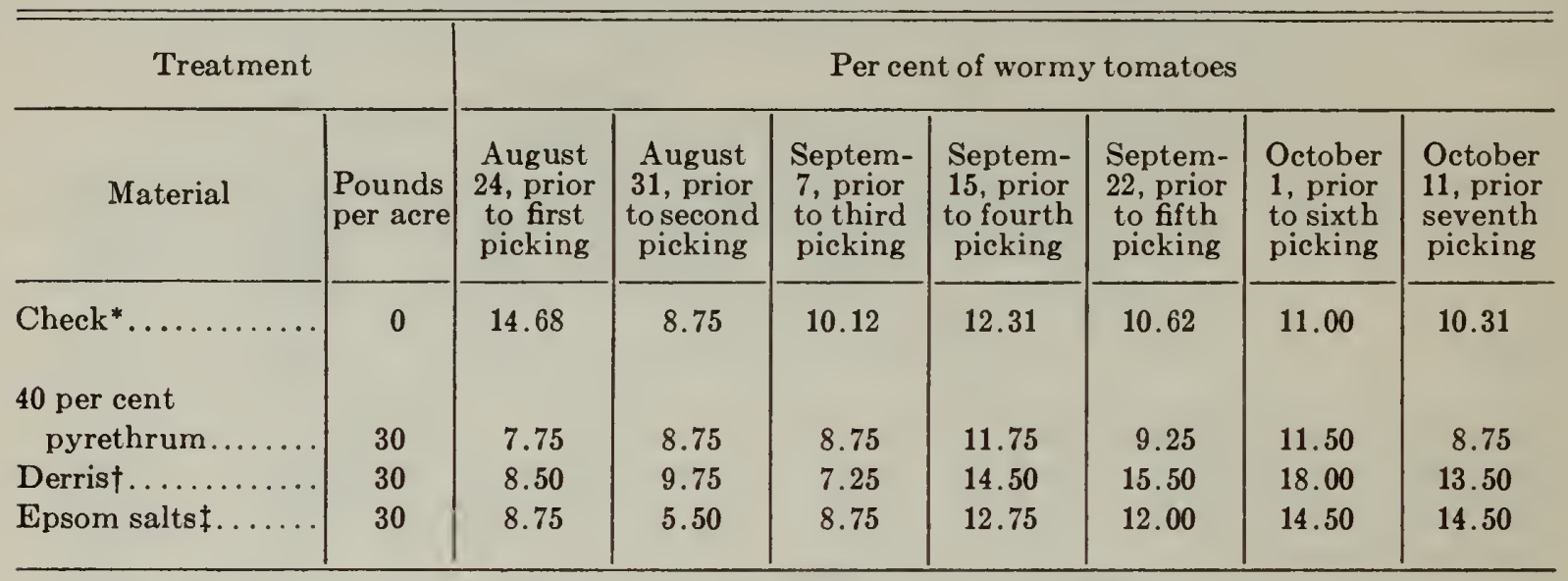

* Checks are the same as used in table 6 . The treated plots considered here were placed along the edge of the main experimental series; they turned out to be much more wormy than the rest, and this accounts for some of the treatments' showing a higher infestation than the checks, which represent a fair average of the entire experimental area.

$\dagger$ Sulfur 80 per cent, rotenone 0.75 per cent.

$\ddagger$ Epsom salts 30 per cent, cocoanut oil 13 per cent, inert material 57 per cent.

TABLE 10

Santa Clara Corn-Earworm-Control Experiments with Pyrethrum, Derris, ANd Epsom SAlts

(Plots dusted August 9, September 2, and October 1, 1937

\begin{tabular}{|c|c|c|c|c|}
\hline \multicolumn{2}{|l|}{ Treatment } & \multicolumn{3}{|c|}{ Per cent of wormy tomatoes } \\
\hline Material & $\begin{array}{l}\text { Pounds } \\
\text { per acre }\end{array}$ & $\begin{array}{l}\text { September } 20, \\
\text { prior to sec- } \\
\text { ond picking }\end{array}$ & $\begin{array}{c}\text { October } 4, \\
\text { prior to third } \\
\text { picking }\end{array}$ & $\begin{array}{l}\text { November } 1 \text {, } \\
\text { prior to fifth } \\
\text { picking }\end{array}$ \\
\hline Check*......... & 0 & 9.12 & 9.93 & 14.25 \\
\hline 40 per cent pyrethrum.. & 30 & 11.50 & 9.00 & 9.50 \\
\hline Derrist............. & 30 & 9.50 & 10.00 & 11.00 \\
\hline Epsom salts $\ddagger \ldots . \ldots \ldots$ & 30 & 12.00 & 10.50 & 11.50 \\
\hline
\end{tabular}

* Checks are the same as shown in table 7 ; see footnote on checks in table 9.

t Sulfur 80 per cent, rotenone 0.75 per cent.

+ Magnesium sulfate 30 per cent, cocoanut oil 13 per cent, inert material 57 per cent.

Jose and Santa Clara. The infestation for these plots was determined in the same manner as for the larger plots, but only 200 fruits were examined instead of 400 per plot. The information obtained is summarized in tables 9 and 10. A glance at the table shows that neither of these materials was effective. The checks used were the same as used in the larger experimental series. It would have been better if the small plots had alternated with checks of their own. This was particularly true at San Jose; for there it so happened that the small plots were placed along the edge of the experimental area which was most heavily infested. This 
accounts for the fact that the infestation in some of the treatments is higher than the average infestation in the checks, which represents the average for the entire experimental area. This work illustrates the desirability of having properly placed checks. In this particular case it made little difference because it was so obvious that pyrethrum, derris, and Epsom salts are not effective against the corn earworm.

Some workers, among them Roney and Thomas (1935), Kadow and Shropshire (1935), and F. L. Thomas (1936), have reported derris as controlling the corn earworm attacking tomatoes. Other investigatorsHeadlee (1935), Huckett and Hervey (1935), Walker and Anderson (1935), Hansberry and Richardson (1936), and van der Vecht (1936)have reported derris as ineffective. Our results confirm those of the latter group. There may, however, be some brand or preparation of derris that is effective; but until this is definitely proved, we strongly advise against derris as an insecticide for the control of the corn earworm.

Thus far we have been unable to find any insecticide among those considered less toxic to man that is as effective against the corn earworm as arsenicals and fluosilicates.

Most Effective Insecticides.-Judging from our results, the best insecticidal dusts to use against the corn earworm attacking tomato are : cryolite, barium fluosilicate, or undiluted commercial calcium arsenate. When the vines are large, the fluosilicates should be used at a strength of not less than 40 per cent and at the rate of 30 pounds per acre. Undiluted commercial calcium arsenate should be applied at the rate of 15 to 25 pounds per acre. Of the three dusts mentioned, calcium arsenate has some advantages over the others in that it is more effective against hornworms.

Time of Application.-Contrary to our former belief, chemical control is of little value early in the season in preventing a serious attack later during the harvest period. Until the first of August, the tomato fields are relatively free from corn earworms. It has already been pointed out that the infestation does not begin at the same time in all areas of the northern tomato-producing region, and that there are numerous localities such as areas near Freeport, Dublin, Gilroy, and Hollister, where, at least for several years at a time, the pest will probably not cause serious injury. In areas where the pest occurs in destructive numbers, the tomato fields must be treated during the harvest period.

Dusting may usually be safely delayed until at least the first of August, but in many localities it can be delayed until a much later date or omitted altogether. The exact time when the insecticide should be applied can most easily be determined by frequent examinations of the 
tomato field. Treatment can be postponed until 2 to 4 per cent of the developing tomatoes, $1 \frac{1}{2}$ to $2 \frac{1}{2}$ inches in diameter, are infested. In determining the infestation, not less than 300 or 400 fruits should be picked and thoroughly examined (particularly at the stem end) to be certain that damage by very small worms is not overlooked.

Frequently an infestation may reach the proportions above mentioned and still not become serious : this has been the case in many surveys. But unless a farmer knows that he is in an area in which the worm damage is not likely to be severe, he should start his control operations at the time suggested above. Over wide areas, farmers dust long before the above condition is reached. In such cases, they usually believe they are getting very good control, whereas, in reality, they would have had clean fruit without applying any insecticide this early in the season.

The corn-earworm situation becomes more severe as the season advances; usually the first few pickings are relatively free from the pest. Because of the seriousness of the late infestation and the necessity for dusting the crop during the harvest, there is a residue problem ; this will be considered later (p. 34).

Insecticidal dusts should be applied only when there is a minimum of air movement and when the tomato vines are somewhat wet with dew. Because the eggs of the corn earworm are laid over the periphery of the vine, the insecticides should thoroughly and evenly cover the plant. If dusting is properly done and the insecticide is not washed off the vines by a rain, a single application should remain effective for from 3 to 4 weeks. Not more than three applications should be necessary to control the pest for the entire harvest.

\section{OTHER METHODS OF CONTROL}

Cultural Methods.-The control of the corn earworm on tomatoes involves a number of factors. It has already been shown that the type of crop grown in a particular region is likely to influence the extent of the damage : for example, in areas where there are large plantings of sweet corn, there is danger of serious infestations. Tomatoes may be protected for a period of time by close proximity of large areas devoted to the culture of preferred hosts such as corn and beans, while these plants are making a rapid and succulent growth. Some evidence in support of this supposition was obtained at San Jose during the past season : Kentucky Wonder beans were planted at different intervals during the entire harvest season, along one side of the experimental plots and the tomatoes nearest this area showed a much lower infestation than the vines on the far side of the experimental area. 
Many pupae can be destroyed by thorough fall plowing which exposes them to the rigors of climate and to their natural enemies. Cultivation probably results in the death of some pupae and also destroys weeds that might serve as hosts for the larvae.

The tomato vines should be destroyed as soon as harvest is complete as a sanitary practice. This would put an abrupt end to any further

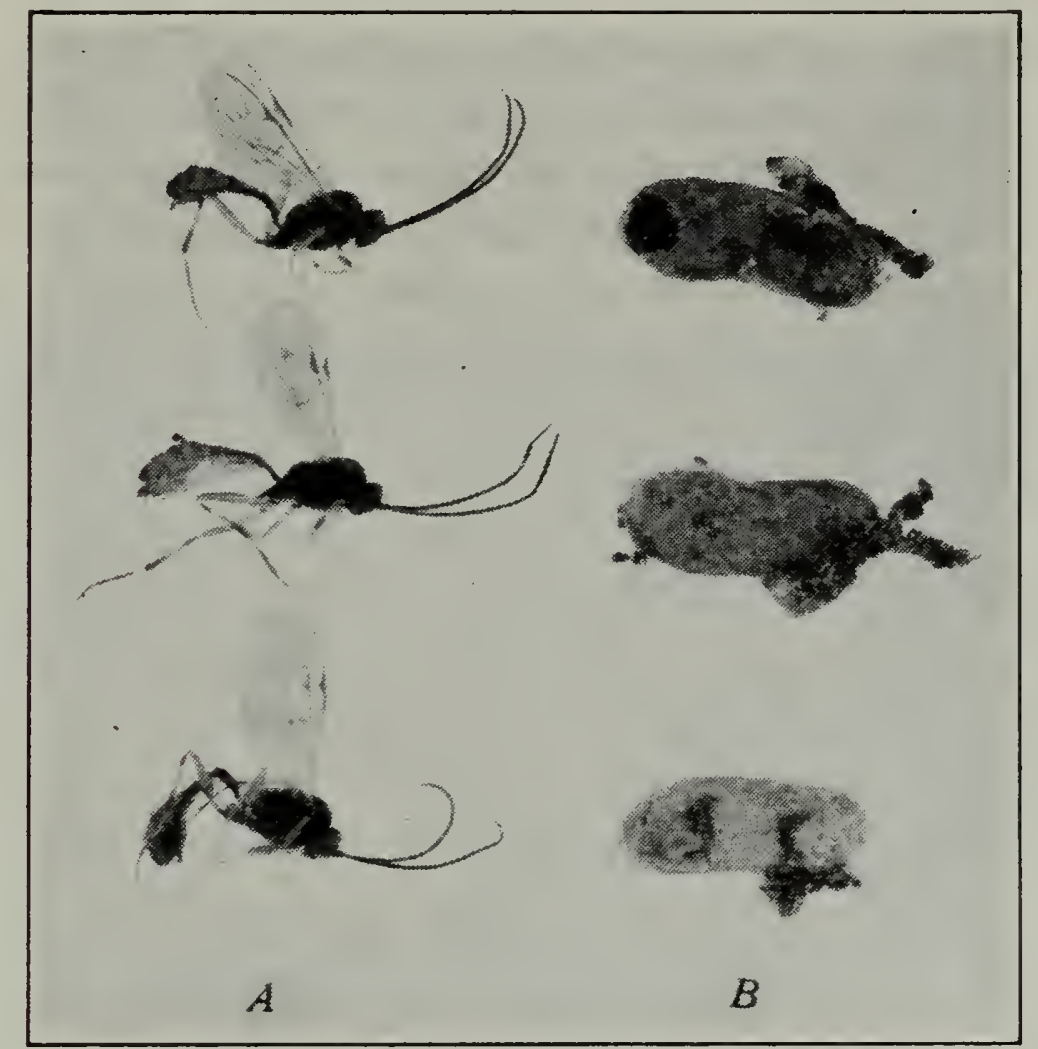

Fig. 11.-Hyposoter exiguae (Vier.), a common hymenopterous parasite of the corn-earworm larva: $A$, adults ; $B$, cocoons with the host skins attached.

build-up in the population, and tend to reduce the number of overwintering forms.

Varieties.-Because the corn-earworm infestation becomes more acute as the season progresses, varieties of tomatoes which mature early in the canning season should be selected. The grower should set his plants in the field early enough so that they come into production as soon as the canning season opens. Tomatoes that mature early may escape a heavy infestation.

Our investigations indicate that pear-shaped tomatoes are probably less seriously injured than the standard varieties.

Parasites.-Each year parasites destroy large numbers of corn-earworm larvae. Probably the most common one encountered is the hymenopterous parasite, Hyposoter exiguae (Vier.) shown in figure 11.

This insect attacks the caterpillars when they are small, and completes its development long before they reach maturity. When mature, the para- 
site larva issues from the caterpillar and spins its cocoon. The parasite cocoons with the host skin lightly attached to one end are often seen scattered here and there over the tomato vines throughout the field. Frequently in examining infested fruit, the cocoons are encountered either on the fruit, protruding from a burrow, or entirely within the fruit. In the latter position, the adult parasite, on emerging from its cocoon, may find no avenue of escape to the outside and thus die within the fruit.

Baits Attractive to the Adult Corn Earworm.-The use of baits probably holds some promise, and we hope to carry on investigations along this line in the near future. Apparently the moths cannot be captured in bait pans for, in feeding, they light on the edge of the container and stick their proboscis into the bait without being caught. Therefore, in order to capture them, some kind of trap would have to be devised. If a suitable combined bait and trap could be developed, the size of the catches might be of value in determining the proper time to apply insecticides.

Light Traps.-During 1936 extensive experimental work with an electrocuting type of monochromatic light was conducted. Considerable information of interest was obtained, and some evidence that lights might be used effectively in capturing adults of the corn earworm. However, much more work is necessary in connection with this phase of the investigation.

\section{CUTWORMS OR ARMYWORMS}

Cutworms or armyworms may attack tomato vines from the time they are transplanted in the field until harvest is complete. At planting time they often cut off the plants at the surface of the soil. Later in the season they may seriously attack the fruit as well as the vine. During the course of this investigation there has been little opportunity to carry out control measures against most species of cutworms. However, any of a number of poison baits can be used; the following, for example, has proved satifactory :

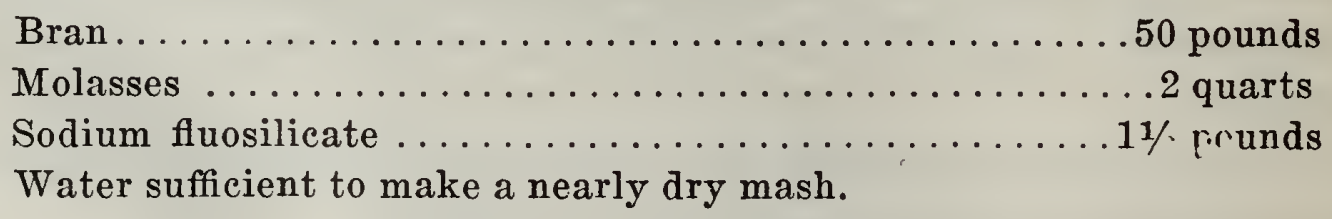

If sodium fluosilicate is not obtainable, paris green or white arsenic can be substituted. The dry ingredients should be thoroughly mixed and the molasses dissolved in water before being added. The mixture should be stirred with just enough water added to moisten the mash. Too much water will cause the mash to be sticky, and difficulty will be encountered 
in spreading it. In mixing baits too much poison should not be added; for according to Stanley (1936):

The amount of poison required to give the best kill was 1-50. Paris green 1-25 and 1-50 showed approximately the same degree of control ... Sodium fluosilicate gave the best kill at 1-50. At 1-25 the concentration of the poison may have been repulsive to the larvae, and 1-100 was too weak. Sodium fluosilicate proved to be superior to paris green at comparable strengths of 1-25 and 1-50.

Because most armyworms feed at night, the best time to scatter the bait is at dusk. This allows a maximum time for the caterpillars to feed, for once a bait drys out, it is no longer very attractive to the pest. If a field is known to be infested, the bait should be broadcast over the field

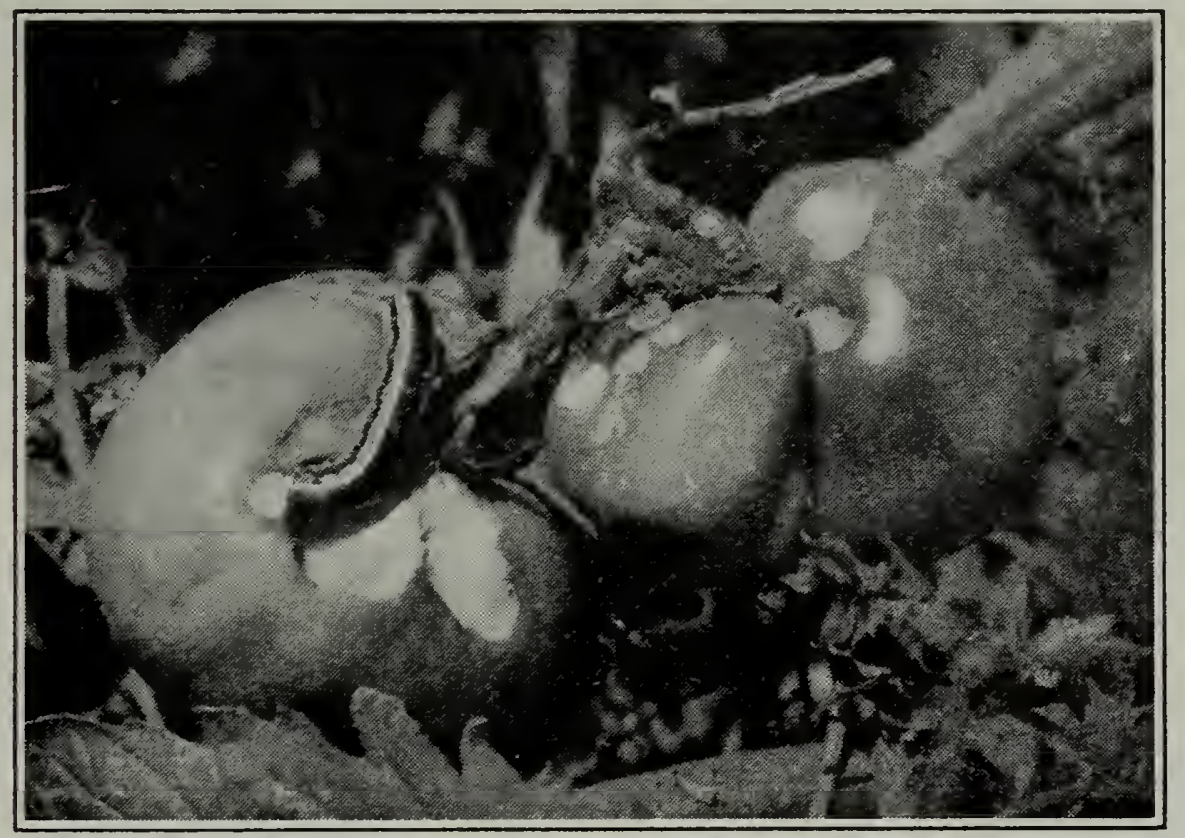

Fig. 12.- Tomato injured by the yellow-striped armyworm, Prodenia praefica Grote.

a day or two before planting. If the plants are already set out and are being injured by cutworms, a small amount of poison bran should be scattered around each plant.

Some caterpillars, such as the yellow-striped armyworm, Prodenia praefica Grote, differ from most cutworms in that they feed during the day and rest on the plants at night. Because of this habit, they cannot be successfully controlled with poison baits scattered over the ground. They can be easily controlled by dusting the vines with undiluted commercial calcium arsenate. During the 1937 season, the yellow-striped armyworm caused considerable damage over a good portion of the northern tomato-producing area. In some fields, the fruit was severely attacked (fig. 12). This is not a serious pest every year, and only now and then does it reach destructive proportions. Unlike the corn earworm, it does not enter the fruit, but eats large irregular holes in its surface. 


\section{TOMATO PINWORM}

\section{LIFE HISTORY}

The tomato pinworm, Gnorimoschema lycopersicella Busck, like the corn earworm, passes through four distinct stages. The adults are small, gray moths about $1 / 4$ inch in length to tips of the folded wings. The eggs, according to C. A. Thomas (1936b), are small and broadly oval. When first laid, they are whitish, but as incubation progresses, the color changes

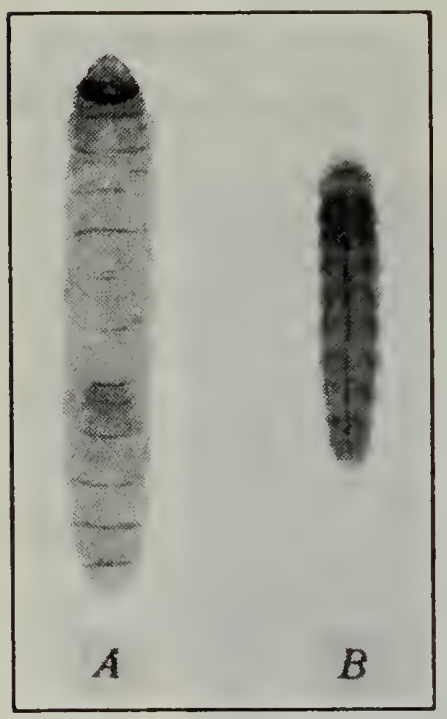

Fig. 13.-A, Fullgrown larva of the potato tuber moth, Gnorimoschema operculella (Zeller) ; $B$, full-grown larva of the tomato pinworm, Gnorimoschema lycopersicella Busck. $(\times 3$.

complete as many as seven generations in one year.

\section{HOST RANGE AND DISTRIBUTION}

The preferred hosts of the pinworm are tomato and potato. It will also attack eggplant, horse nettle (Solanum carolinense), and blue witch nightshade (Solanum umbelliferum).

During recent years, the pinworm has been extending its range rather rapidly in parts of the United States. It is reported from the following states : California, Delaware, Florida, Mississippi, Missouri, New Mexico, Pennsylvania, and Virginia. Outside of the United States, Elmore (1937) reports it from the Bahamas, Bermuda, Cuba, Haiti, Hawaii, Mexico, and Peru.

In California, the pest has been slowly extending its range. It occurs throughout the southern portion of the state and northward in the San 

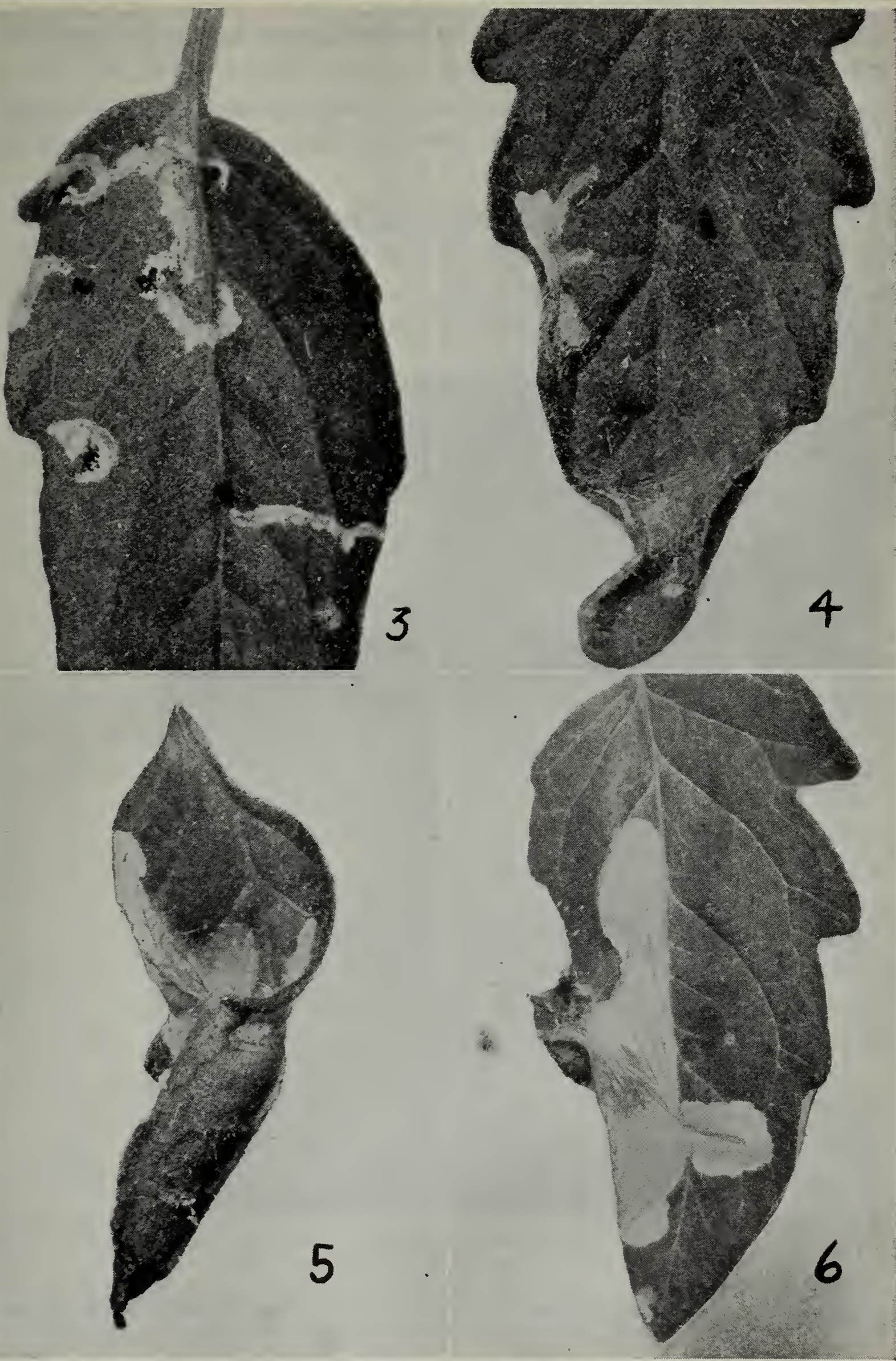

Fig. 14.-3, Work of tomato pinworm, 4 days old ; 4 and 5 , folding of leaf tip or leaf by larva which has left its burrow; 6 , leaf after pinworm has left plant to pupate. Note undisturbed epidermal layers. (Photographs by Campbell and Elmore; courtesy of California State Department of Agriculture.) 
Joaquin Valley as far as Modesto. It is also present in small numbers in the region about San Francisco Bay.

A detailed account of the pest in the East is given by C. A. Thomas $(1933,1936 a, 1936 b)$ and in California by Campbell and Elmore (1931, 1935), and Elmore (1937).

\section{DESTRUCTIVENESS}

In California, New Mexico, and Florida, the tomato pinworm is a pest of field-grown tomatoes, while in the cooler regions of the United States, it is mainly a serious pest of tomatoes grown under glass. In the southern

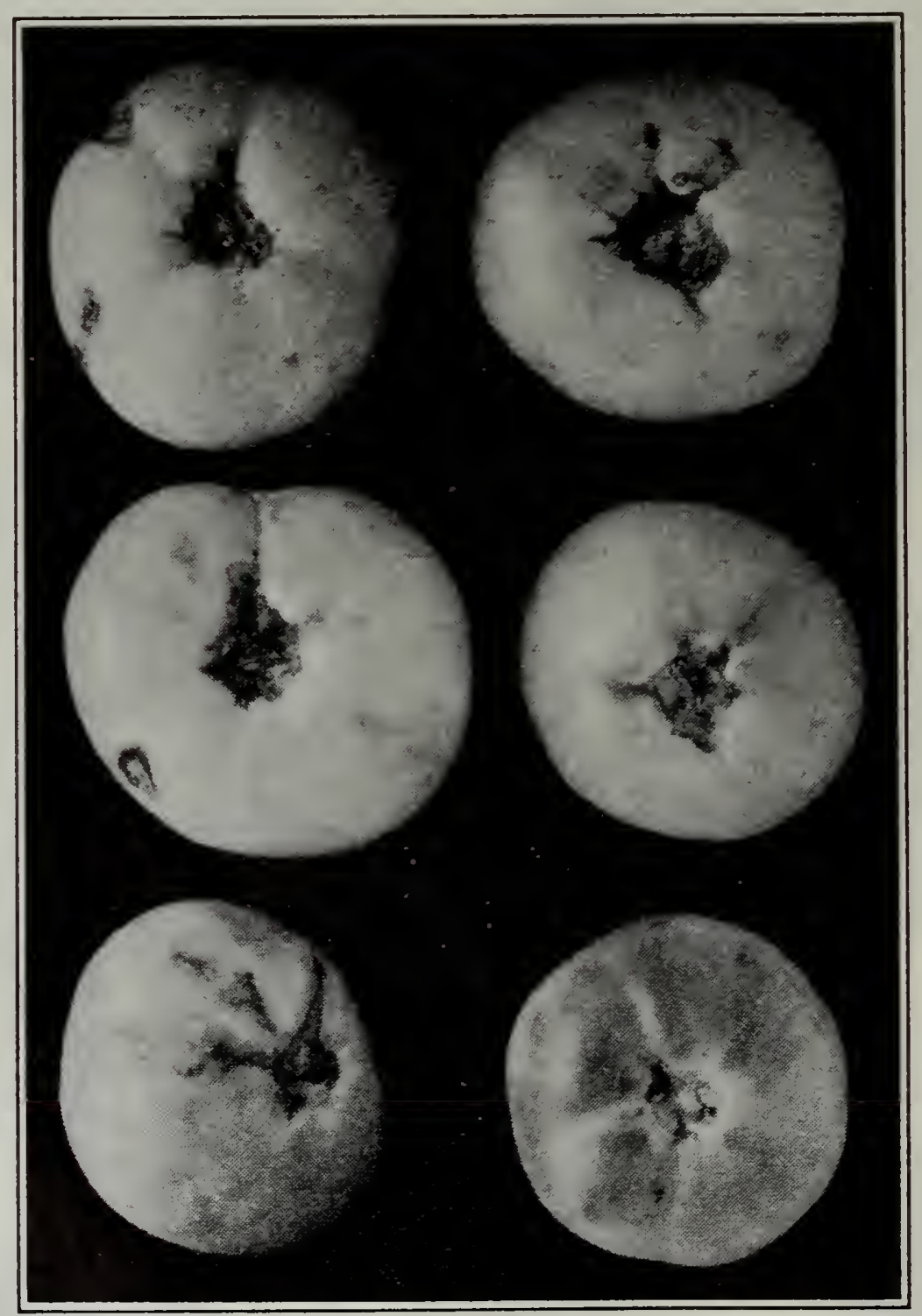

Fig. 15.-Tomatoes seriously infested with the tomato pinworm, showing the several types of injury.

part of this state, it is probably the most destructive insect attacking the tomato fruits and is also capable of causing serious injury to the foliage.

The nature of the injury is shown in figure 14, which has been taken from Campbell and Elmore (1935). The larvae commonly attack the fruit (fig. 15) at the stem or calyx end, although they may enter the fruit 
at other points. The larvae that enter the calyx, generally confine their activity to the core, while those that enter at other points usually feed on the flesh just beneath the skin. Because of their small size, they do not penetrate very far into the core, and the coring of the fruit usually removes them. More than one larva may attack a single fruit. After infested fruits are picked, the larvae spin webs over the entrances to their burrows, which sometimes makes their presence and injury difficult to detect.

Because the pinworm can pass through a number of generations in a year, it becomes more serious as the season advances; greatest damage is likely to occur where tomatoes are produced from early in the growing season to late in the fall. Up to the present time, this pest has caused little damage in the northern tomato-producing areas, yet there were several serious infestations late in the season about Merced and Modesto. Although the insect is present in the San Francisco Bay area, not more than 0.1 per cent of the fruit was infested during the 1937 season.

\section{CONTROL}

No satisfactory chemical control has yet been perfected, but cultural practices are very important in restricting the seriousness of the infestation. It is highly desirable to destroy tomato vines as soon as harvest is complete. This can be done by either disking and plowing under the plants while still green or by pulling the vines and placing them in small piles or windrows and burning them at the earliest opportunity. Vines should never be left in large piles along the borders of the field or elsewhere; for Elmore (1937) has shown that such conditions greatly favor the development and overwintering of the pest. Therefore, vines that are not destroyed as soon as harvest is complete may cause a local build-up of large populations which may be an important factor in carrying the pest over from one crop to another. Needless to say, other host plants should be destroyed.

In an area where the pest is likely to be serious, the growing of but a single crop of tomatoes may be desirable in order to lessen the danger of a build-up. From limited observations about Visalia, we noted in 1936 that the early spring crop was only slightly infested. At the close of the harvest, the pest had increased in fair numbers, and if a summer crop had been planted, it is almost certain that extensive damage would have occurred. As long as only one crop is grown in such an area, serious damage is not likely to occur. 


\section{POTATO TUBER MOTH}

\section{LIFE HISTORY}

The potato tuber moth, Gnorimoschema operculella (Zeller) (Phthorimaea), has a life cycle very similar to that of the tomato pinworm. It passes through a number of generations each year, and in storage, if food is present and the temperature does not fall too low, breeding continues throughout the year. The length of a life cycle varies from about one month in the summer to three or more months in the winter. In areas where it is able to survive the winters, it probably passes through periods of low temperatures as a full-grown larva or pupa.

The adults are small and gray with silvery bodies and minute dark specks on the forewings. They are nocturnal. Each female may lay from 150 to $200 \mathrm{eggs}$, which are small, oval, pearly white, and are deposited indiscriminately over the plant. The larvae (fig. 13, A) molt four times. When full-grown, they are slightly more than $3 / 8$ inch in length, and are either white, yellow, pinkish, or greenish, with the head and prothoracic shield dark brown. Pupation occurs in a white silken cocoon in any secluded place, on the host, in the surface soil, sacks, or storage bins. In tomato fields, most larvae probably pupate in or on the surface soil.

\section{HOST RANGE AND DESTRUCTIVENESS}

The hosts of the potato tuber moth are apparently limited to solanaceous plants, including potato, tomato, tobacco, Jimson weed, pepper, horse nettle, eggplant, and nightshade.

Tomatoes are subject to attack by the larvae of the potato tuber moth over a large portion of the tomato-growing area of California. In some areas, such as Yolo and Sacramento counties, the pest has not been collected in tomato fields. Apparently the tuber moth larva is only likely to cause serious damage in the coastal regions which have a milder and more moderate climate although there are reports of either this insect or the pinworm seriously attacking tomatoes in the Stockton district. Although the tuber moth may feed on other parts of the plant, damage is serious only on the fruit.

In some cases an infestation as high as 57 per cent has been encountered, although in most fields it is usually less than 5 per cent. It builds up as the season advances, and therefore is most serious late in the harvest. Early in the season, very few infested tomatoes are encountered; but from late September to the end of the growing season, at least a few infested fruits will be found in most of the tomato fields of the coastal area. 


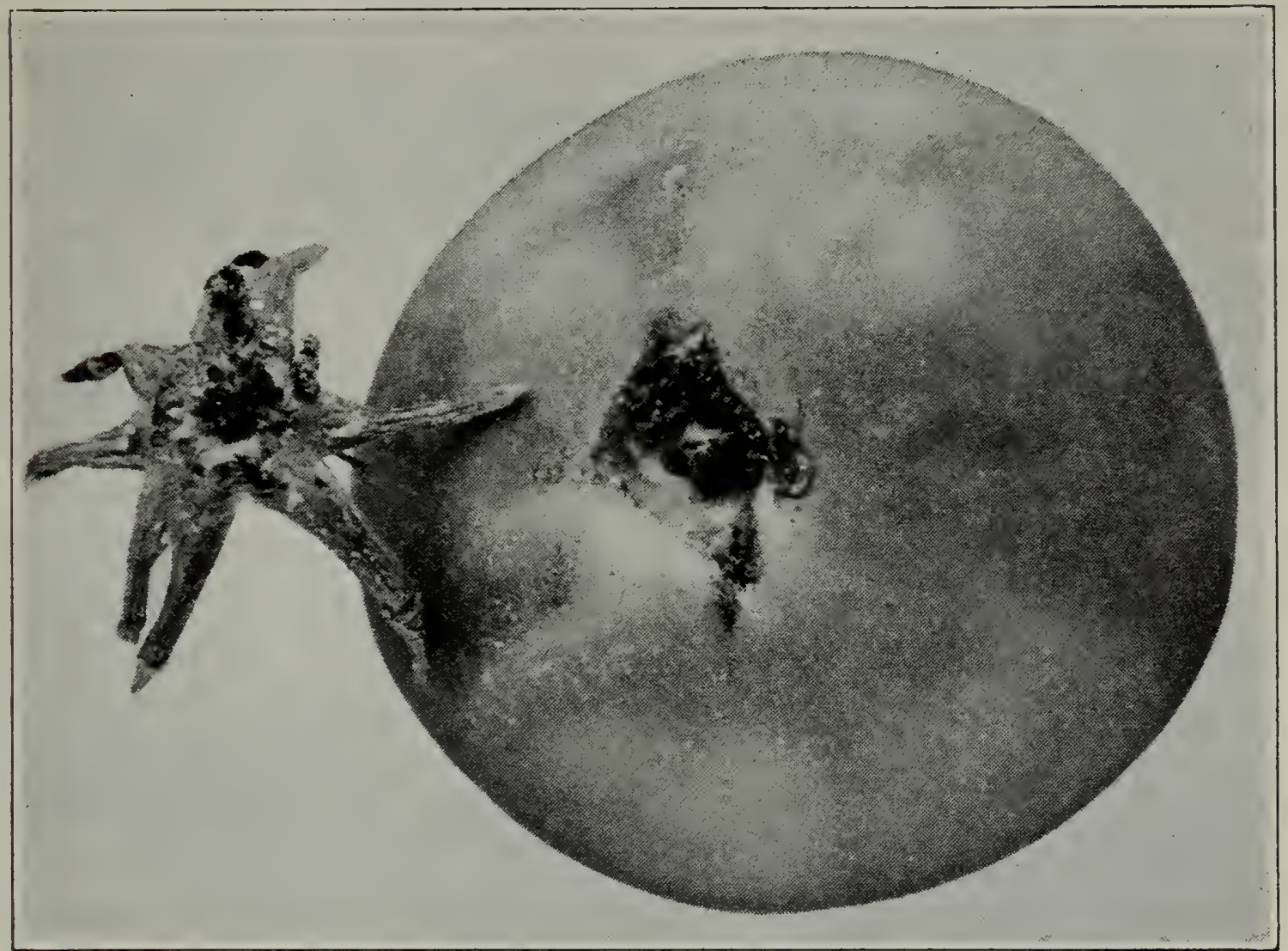

Fig. 16.-Tomato infested at the calyx end by the larva of the potato tuber moth. The calyx has been removed revealing the excrement and entrances to the burrows. (From Ext. Cir. 99.)

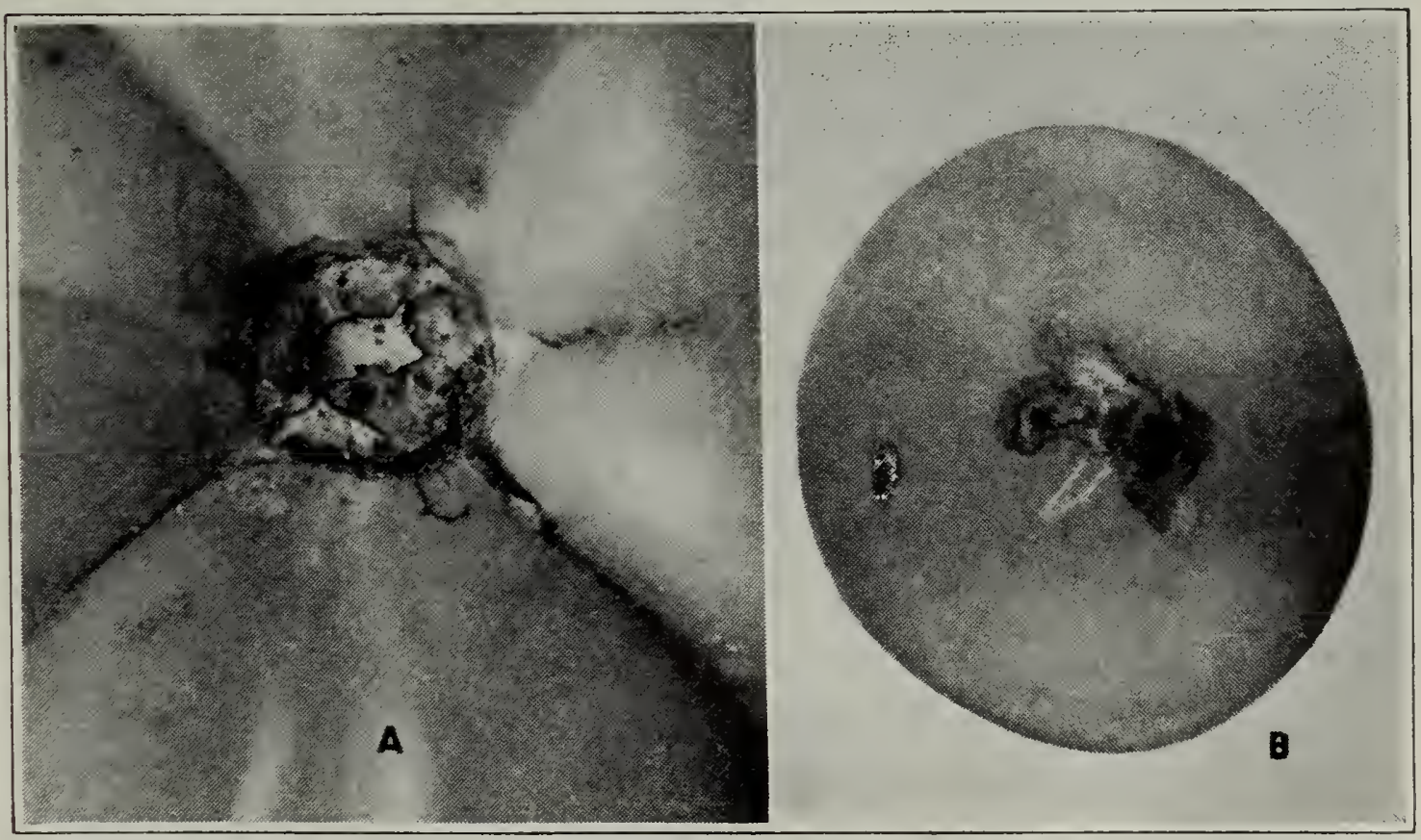

Fig. 17.-Work of the potato-tuber-moth larvae on tomatoes: $A$, enlarged view of the calyx end showing the webbing over the burrow entrances; $B$, larval mines just below the skin. (From Ext. Cir. 99.) 
Because the injured fruit is rather difficult to detect, infestations, even though low, are of considerable annoyance. The larvae prefer to enter the fruit at the calyx end, and seem to be more numerous in those varieties of tomatoes which have firm, solid flesh. When entry is made at the calyx end, the burrows follow the core and the fleshy portions that radiate from it. In the early stages the burrows do not extend far into the fruit, but as the larvae increase in size, they may penetrate deep into the interior. When the calyx is removed, the entrances to the burrows are usually opened (fig. 16). After the fruit has been picked for some little time, the larvae, if still present, close the entrance to the burrows with a webbing and the calyx end of the fruit appears as shown in figure 17, $A$. As this webbing tends to obscure the injury, the fruit must be carefully observed or the damage will pass unnoticed.

The potato-tuber-moth larvae will attack the fruit at any place. Where entrance is made at some point other than the calyx, the larvae may act as miners and work just below the epidermis as illustrated in figure 17, $B$. They may penetrate deeper into the fruit if they encounter a fleshy part that radiates from the core.

A large number of larvae may enter a single fruit, although from one to three are the numbers most commonly found. Their way of working and the type of damage done is very similar to that caused by the tomato pinworm. However, because of their larger size, the injury may be slightly more noticeable.

\section{CONTROL}

Because serious injury to tomatoes has been very scattered, no opportunity has arisen to test insecticides against the potato tuber moth. Proper cultural methods and crop rotation, however, will no doubt help considerably in holding this pest in check. Whenever a serious infestation was encountered, it occurred either in a locality where potatoes were being grown or in a field where potatoes had previously been planted. Russell (1933) made similar observations and reported that tomatoes should not be planted after potatoes because of the likelihood that enough insects will be present on tubers and volunteer potato plants to cause a serious infestation.

\section{TOMATO WORM AND TOBACCO WORM}

\section{LIFE HISTORY}

Over part of the tomato-growing area of the state, the tomato worm, Protoparce sexta (Johan.) and the tobacco worm, P. quinquemaculata (Haw.), are very destructive to tomatoes. The adults (fig. 18, $B$ ) of these insects, known as "sphinx moths" or "hummingbird moths," are swift fliers. In the northern tomato-producing area, the adult moths may 


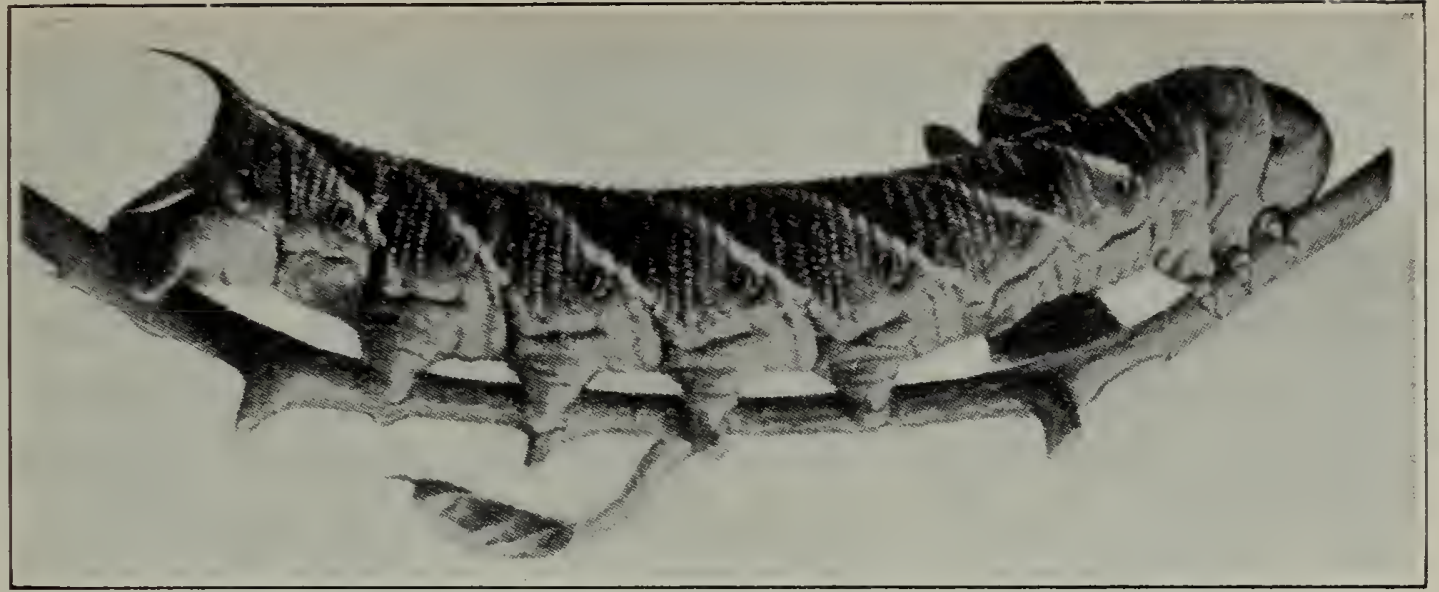

$A$

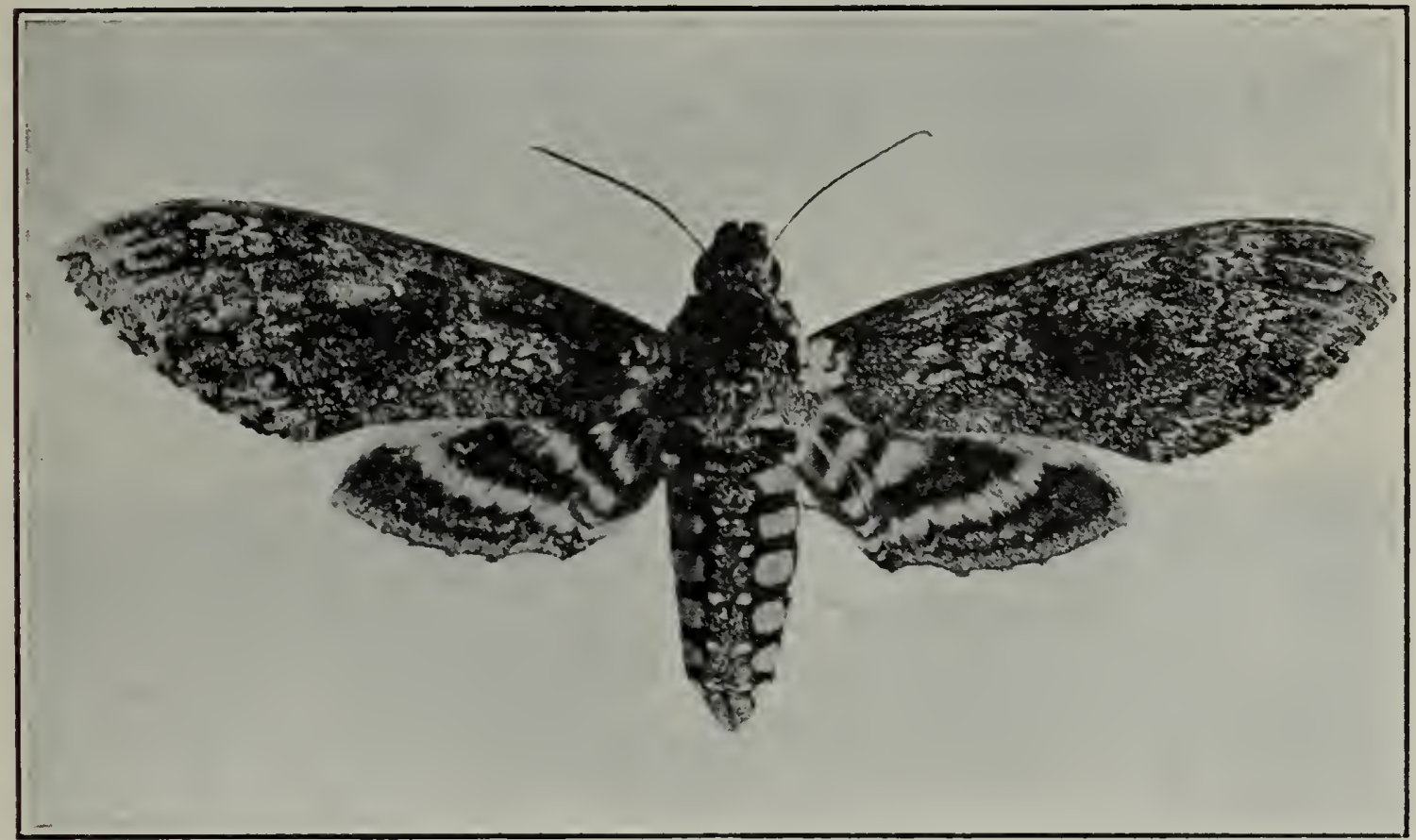

$B$

Fig. 18. - The tomato worm, Protoparce sexta (Johan.) : A, larva (after Folsom) ; $B$, adult. (From Ext. Cir. 87.)

emerge from the overwintering pupae (fig. 19) early in June. They lay their large greenish eggs at random over the tomato vines. The larvae (fig. 18, $A$ ), sometimes called "hornworms," are large green or brown worms, often attaining a length of 4 inches. There are probably no less than three generations in a season, and the winter is passed in the pupal stage in the soil.

They strip the leaves from the vines as shown in figure 20. When they are abundant, serious damage may also be done to the developing fruit (fig. 21). Although they may occur in any tomato-growing area, they are most serious in the warmer interior valleys, and if severe infestations are allowed to go unchecked, an entire field may be defoliated. 


\section{CONTROL}

Early in the season when the vines are small, the worms can be partially held in check by hand-picking, but as the vines grow and the infestation increases, it may become necessary to dust the tomato fields with an insecticide. In 1936 a heavy infestation of hornworms occurred in the experimental area on Union Island. At first we hand-picked the worms, but by July 17 the infestation became so serious that dusting

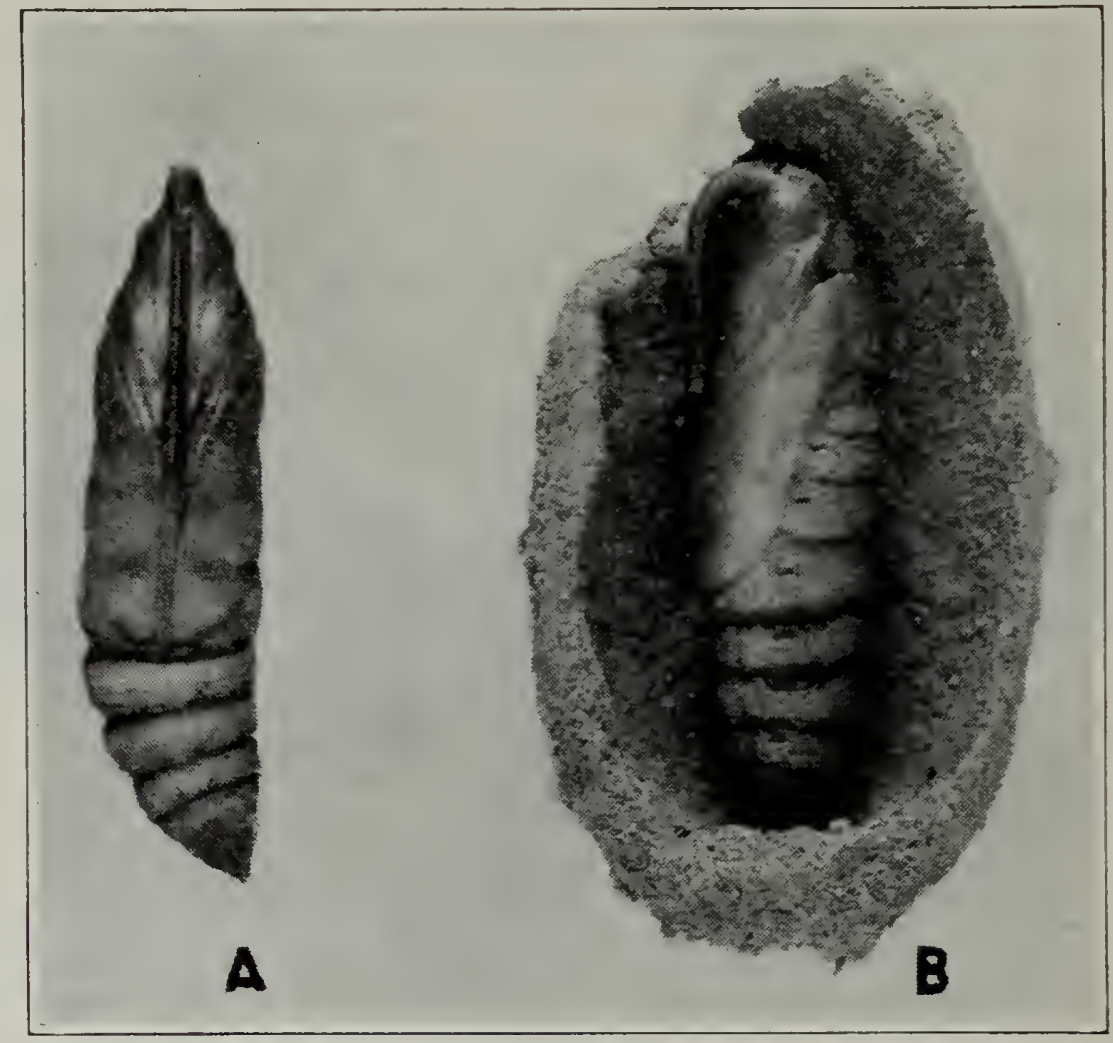

Fig. 19.-A, Pupa of the tobacco worm, Protoparce quinquemaculata (Haw.), $B$, pupa of the tomato worm, $P$. sexta (Johan.), in its cell. The distinguishing character that separates the two species is the sheathed proboscis, which is longer in the tomato worm. (From Ext. Cir. 99.)

became necessary. The damage was checked, but by August 24, injury was increasing and the area was therefore dusted for a second time. This dusting was sufficient to control the pest, although on September 25 the experimental area was again dusted because a corn-earworm infestation was developing. The materials used were calcium arsenate, lead arsenate, cryolite, barium fluosilicate, and sodium fluosilicate. The arrangement of the plots and the composition of the insecticides were the same as used for the corn earworm for 1936 (see p. 12 and fig. 9).

At various intervals, the plots were examined for hornworms and injured plants. No note was made of the degree of injury, but the total number of damaged plants and the number of worms found in each plot were recorded. In making the surveys, a buffer row was left around each 


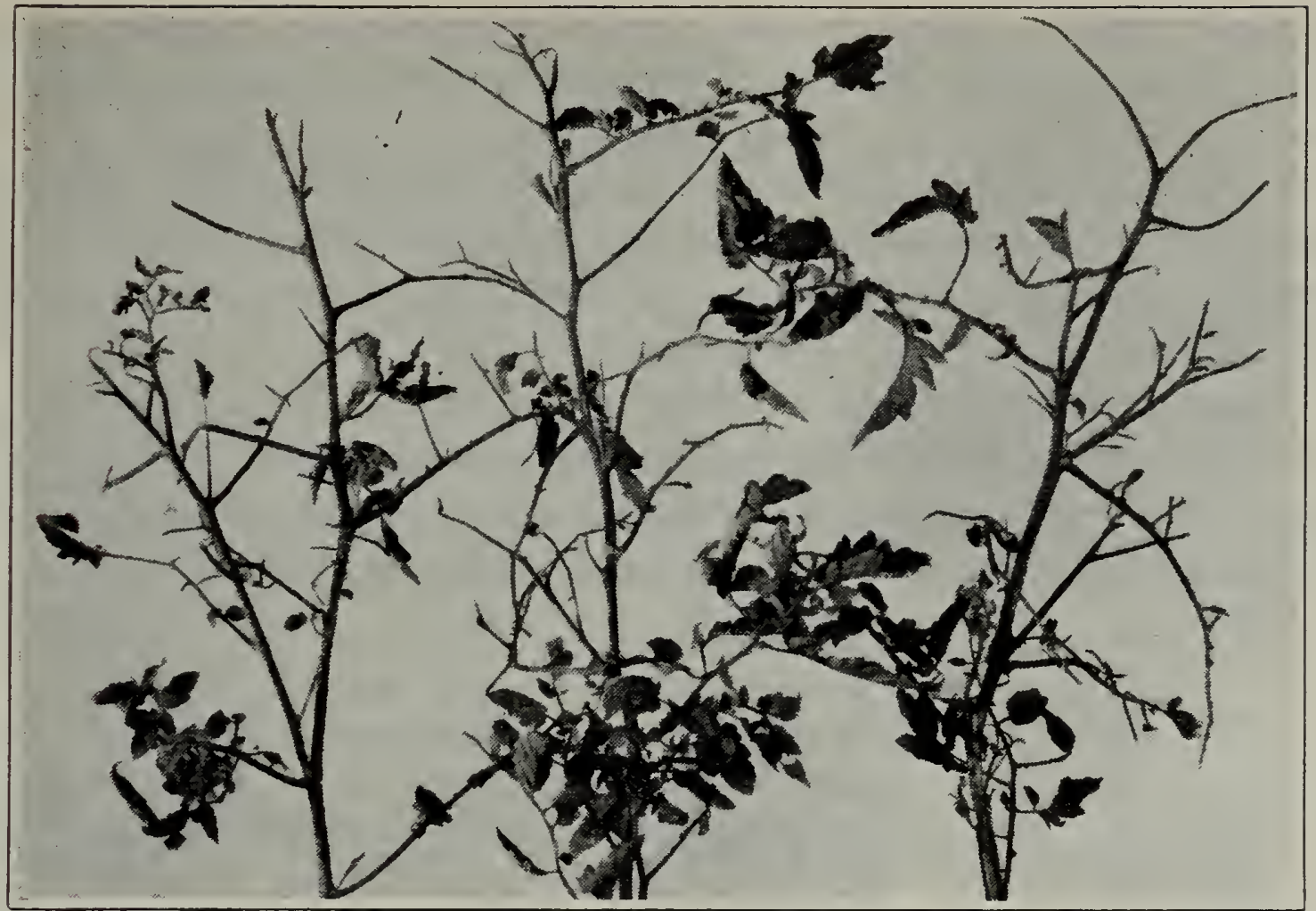

Fig. 20.-Tomato stems that have been nearly defoliated by caterpillars of the tomato worm. (From Ext. Cir. 99.)

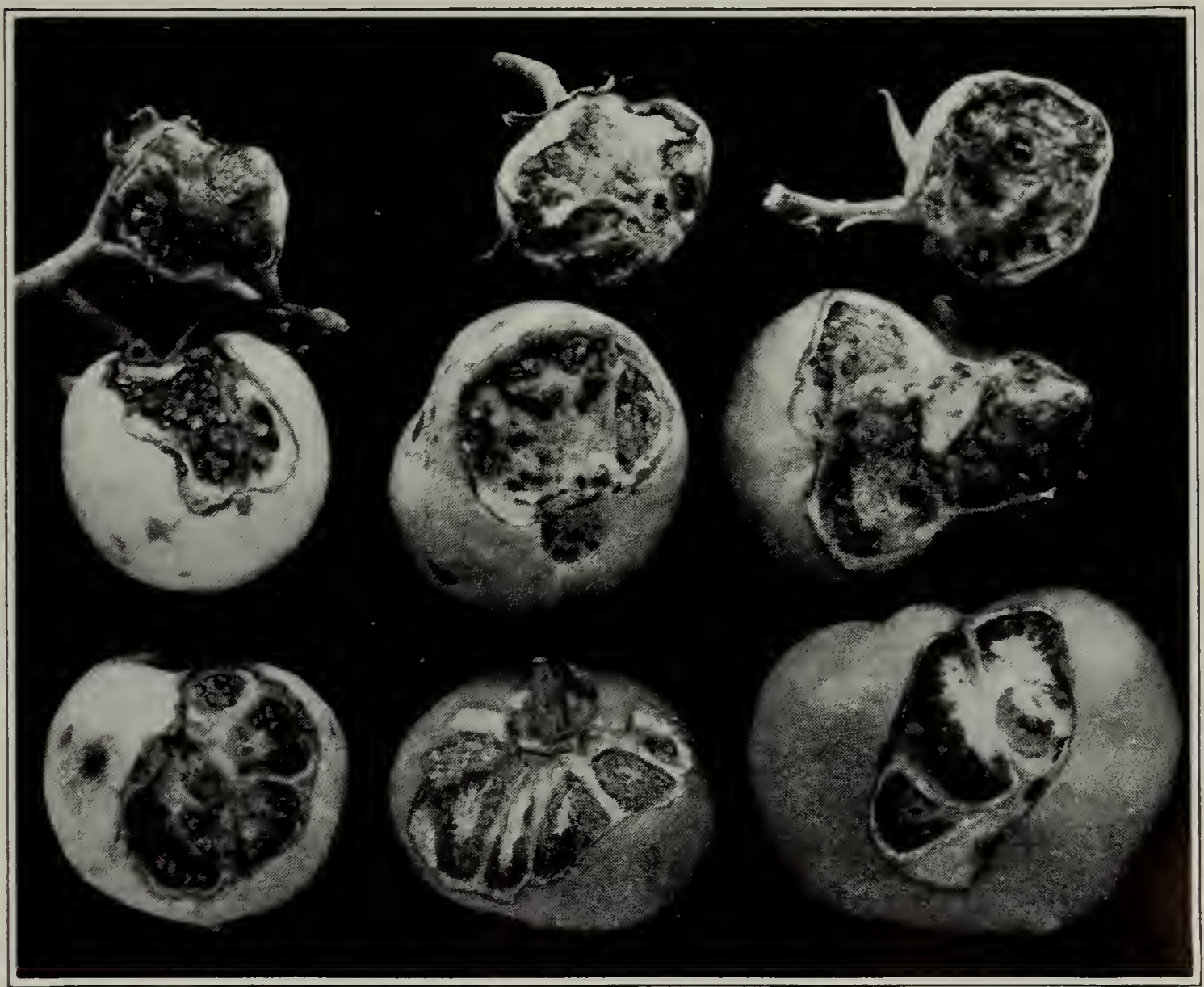

Fig. 21.-Tomato fruits injured by the caterpillars of the tomato worm. (From Ext. Cir. 99.) 
plot in which the injured plants were not counted. The interval between surveys was usually, but not always, sufficiently long so that the injury observed in the previous survey was covered up by new growth.

The results of these surveys are summarized in table 11. The arsenicals gave the best control; calcium arsenate proved nearly as effective as lead arsenate. Because of the possible residue problem, we recommend calcium arsenate in preference to lead arsenate.

Apparently, dusting during July will sometimes be necessary to control hornworms. Later dustings may also be necessary, but these will serve two purposes in that they will not only control hornworms, but will also control any corn-earworm infestations that might be developing.

TABLE 11

Hornworm Control ExPERIMENTS ON Union IsLand

(Plots dusted July 17, August 24, and September 25, 1936*)

\begin{tabular}{|c|c|c|c|c|c|c|c|}
\hline \multicolumn{2}{|l|}{ Treatment } & \multicolumn{2}{|c|}{$\begin{array}{l}\text { August } 23,1936, \\
37 \text { days after } \\
\text { first dusting }\end{array}$} & \multicolumn{2}{|c|}{$\begin{array}{c}\text { September } 7,1936 \\
14 \text { days after } \\
\text { second dusting }\end{array}$} & \multicolumn{2}{|c|}{$\begin{array}{c}\text { September } 21,1936 \\
28 \text { days after } \\
\text { second dusting }\end{array}$} \\
\hline Material & $\begin{array}{l}\text { Pounds } \\
\text { per acre }\end{array}$ & $\begin{array}{l}\text { Number } \\
\text { of plants } \\
\text { injured }\end{array}$ & $\begin{array}{l}\text { Number } \\
\text { of worms } \\
\text { found }\end{array}$ & $\begin{array}{l}\text { Number } \\
\text { of plants } \\
\text { injured }\end{array}$ & $\begin{array}{l}\text { Number } \\
\text { of worms } \\
\text { found }\end{array}$ & $\begin{array}{l}\text { Number } \\
\text { of plants } \\
\text { injured }\end{array}$ & $\begin{array}{l}\text { Number } \\
\text { of worms } \\
\text { found }\end{array}$ \\
\hline Check. & 0 & 65 & 25 & 104 & 40 & 117 & 8 \\
\hline 40 per cent cryolite. & 30 & 42 & 10 & 59 & 16 & 83 & 10 \\
\hline 40 per cent barium fluosilicate. & 30 & 41 & 11 & 47 & 13 & 69 & 7 \\
\hline $\begin{array}{l}40 \text { per cent sodium fluosilicate. } \\
\text { Straight commercial calcium }\end{array}$ & 30 & 53 & 11 & 59 & 19 & 77 & 11 \\
\hline 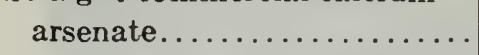 & 15 & 27 & 12 & 15 & 3 & 20 & 3 \\
\hline 50 per cent lead arsenate..... & 20 & 22 & 9 & 8 & 2 & 5 & 1 \\
\hline
\end{tabular}

* The dust applied on September 25 was directed mainly against the corn earworm.

\section{RESIDUE}

These experiments have shown that to control the corn earworm and hornworms successfully, dusting tomato fields during the harvest period is necessary. This at once brings up the problem of residue, and therefore during 1936 considerable work was done in coöperation with the Canners' League of California and the Western Branch laboratory of the National Canners' Association to determine whether or not poisonous residue could be successfully removed from tomatoes grown for the cannery.

Tomatoes obtained from the various experimental series were anal$\mathrm{yzed}^{5}$ for residue. All samples were taken from plots that had been handdusted. In order to make the test as severe as possible, only those tomatoes which showed the greatest amount of residue were picked in taking sam-

${ }^{5}$ All the analytical work was done in the National Canners' Association Laboratories by W. F. Eberz and F. C. Lamb. 
TABLE 12

Analysis of Tomatoes Dusted with Calcium Arsenate

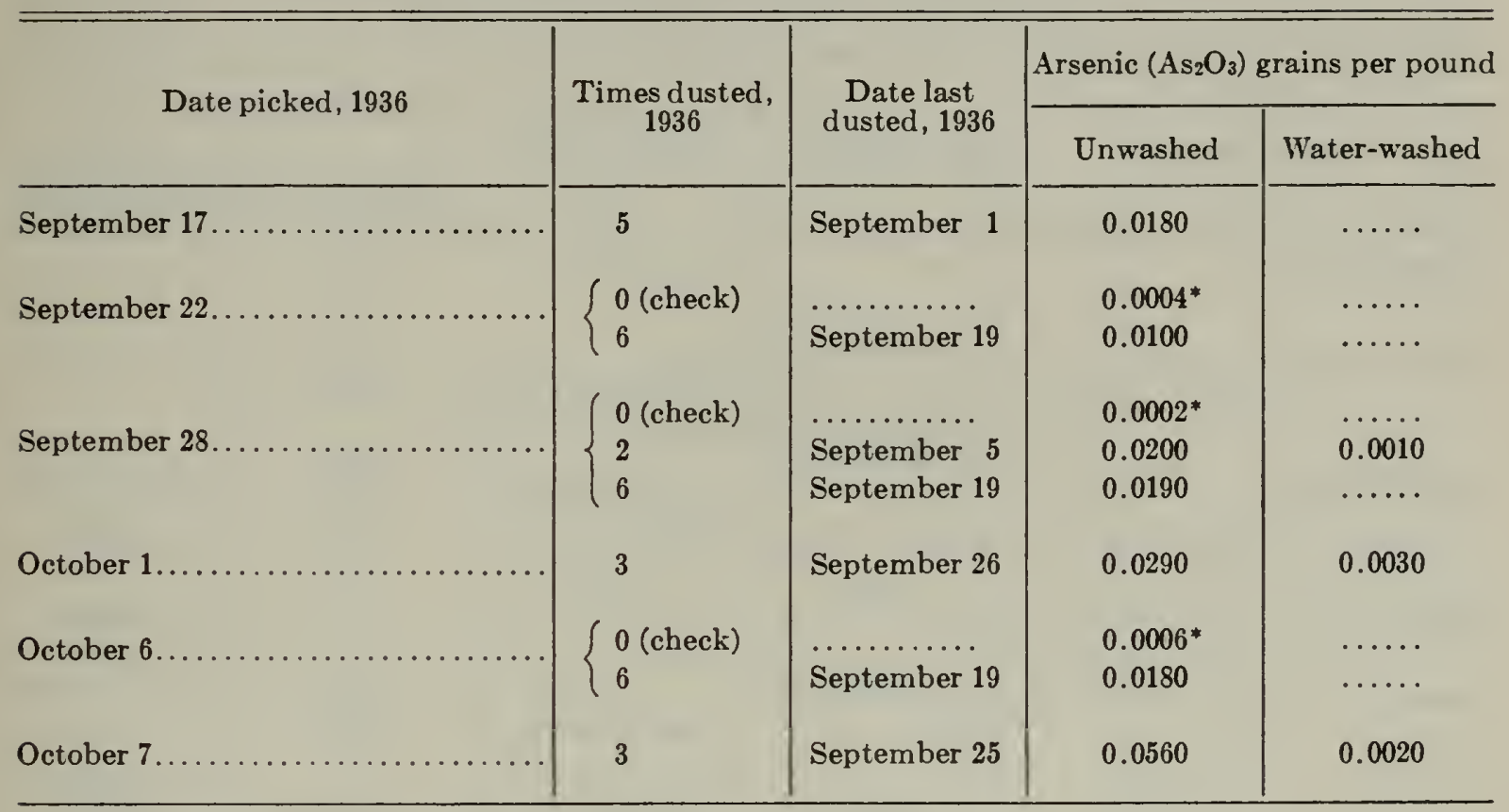

* Some drift from adjacent dusted plots may have occurred.

\section{TABLE 13}

Analysis of Tomatoes Dusted with 50 Per Cent Lead Arsenate at the Rate of 20 Pounds Per ACRE

\begin{tabular}{|c|c|c|c|c|c|c|}
\hline \multirow{2}{*}{ Date picked, 1936} & \multirow{2}{*}{$\begin{array}{c}\text { Times } \\
\text { dusted, } 1936\end{array}$} & \multirow{2}{*}{$\begin{array}{c}\text { Date last } \\
\text { dusted, } 1936\end{array}$} & \multicolumn{2}{|c|}{$\begin{array}{l}\text { Lead }(\mathrm{Pb}) \\
\text { grains per pound }\end{array}$} & \multicolumn{2}{|c|}{$\begin{array}{l}\text { Arsenic }\left(\mathrm{As}_{2} \mathrm{O}_{3}\right) \\
\text { grains per pound }\end{array}$} \\
\hline & & & Unwashed & $\begin{array}{l}\text { Water- } \\
\text { washed }\end{array}$ & Unwashed & $\begin{array}{l}\text { Water- } \\
\text { washed }\end{array}$ \\
\hline September $17 \ldots$ & 5 & September 1 & 0.0318 & $\ldots \ldots$ & 0.0190 & $\ldots \ldots$ \\
\hline \multirow{2}{*}{ September $22 \ldots \ldots \ldots$} & 0 (check) & $\ldots \ldots \ldots$ & $0.0004^{*}$ & & $0.0004^{*}$ & \\
\hline & 6 & September 19 & 0.0410 & $\ldots \ldots$ & 0.0230 & $\ldots \ldots$ \\
\hline \multirow{3}{*}{ September 28.} & 0 (check) & & 0.0000 & & 0.0002 & \\
\hline & 6 & September 19 & 0.0334 & $\ldots \ldots$ & 0.0170 & $\ldots \ldots$ \\
\hline & 2 & September 5 & 0.0470 & 0.0049 & 0.0320 & 0.004 \\
\hline October $1 \ldots$ & 3 & September 26 & 0.0051 & 0.0006 & 0.0190 & 0.002 \\
\hline \multirow[t]{2}{*}{ October 6 . } & 0 (check) & $\ldots \ldots \ldots \ldots$ & $0.0002^{*}$ & $\ldots \ldots$ & $0.0006^{*}$ & $\ldots \ldots$ \\
\hline & 6 & September 19 & 0.0329 & $\ldots \ldots$ & 0.0200 & $\ldots \ldots$ \\
\hline October 7 .. & 3 & September 25 & 0.0205 & 0.0037 & 0.0130 & 0.002 \\
\hline
\end{tabular}

* Some drift from adjacent dusted plots may have occurred. 


\section{TABLE 14}

Analysis of Tomatoes Dusted with 40 Per Cent Barium Fluosilicate at the Rate of 30 Pounds Per Acre

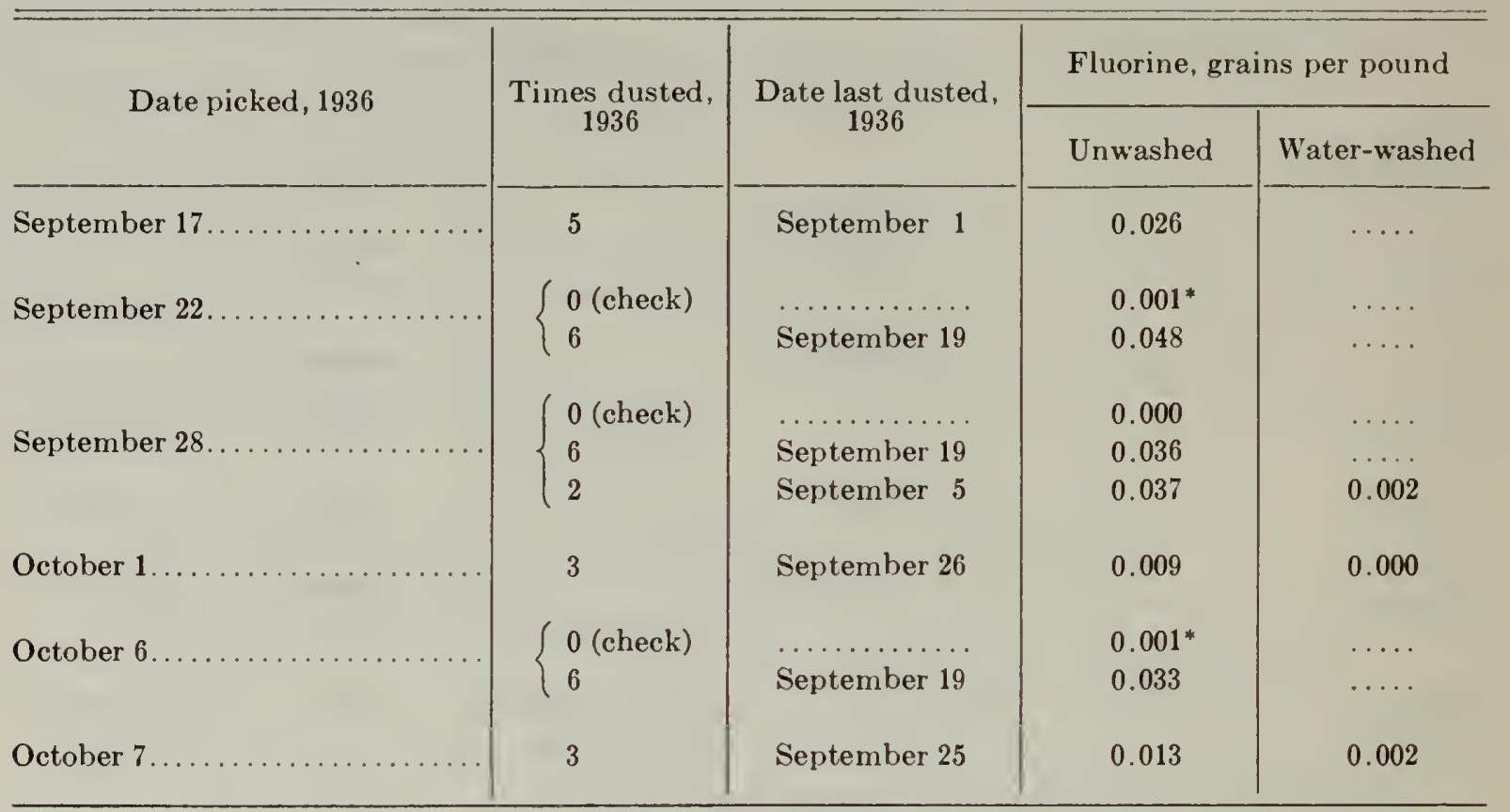

* Some drift from adjacent dusted plots may have occurred.

\section{TABLE 15}

Analysis of Tomatoes Dusted with 40 Per Cent Sodium Fluosilicate at the Rate of 30 Pounds Per Acre

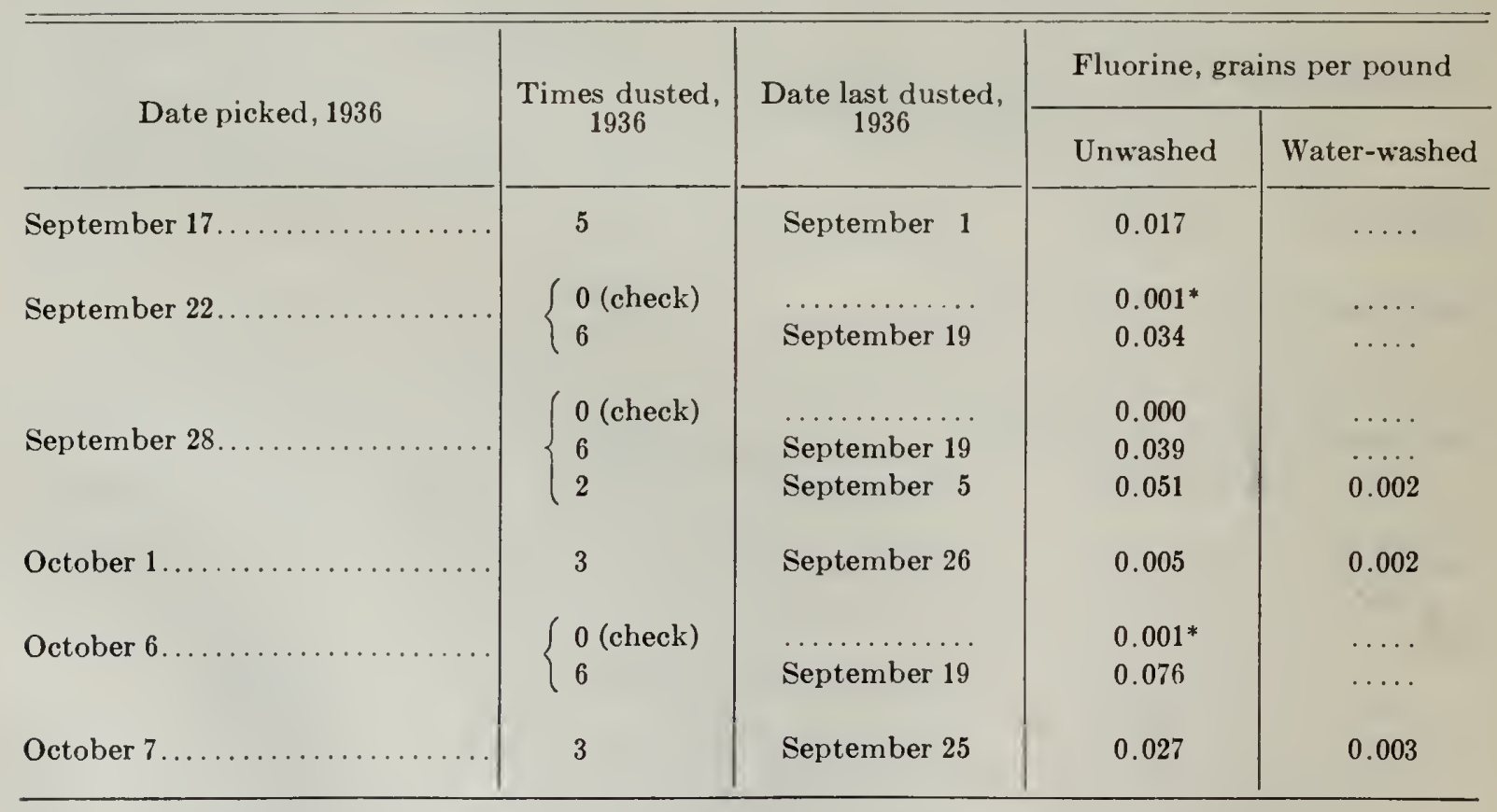

\footnotetext{
* Some drift from adjacent dusted plots may have occurred.
} 
ples. In order to determine the effectiveness of washing, samples were sometimes divided into two parts. One portion received no treatment and the other was passed through a regular cannery washer before being analyzed. In every case where the fruit was washed, the residue was reduced to well below the legal tolerance. In other tests, the fruit was first immersed in a bath containing 1 per cent hydrochloric acid for $30 \mathrm{sec}-$ onds, and then passed through the regular cannery washer. This treatment so effectively removed the residue that even if the trimmings were

\section{TABLE 16}

Analysis of Tonatoes Dusted with 40 Per Cent Cryolite at the Rate of 30 Pounds Per Acre

\begin{tabular}{|c|c|c|c|c|}
\hline \multirow{2}{*}{ Date picked, 1936} & \multirow{2}{*}{$\begin{array}{c}\text { Times dusted, } \\
1936\end{array}$} & \multirow{2}{*}{$\begin{array}{l}\text { Date last dusted, } \\
1936\end{array}$} & \multicolumn{2}{|c|}{ Fluorine, grains per pound } \\
\hline & & & Unwashed & Water-washed \\
\hline September 17 . & 5 & September 1 & 0.025 & \\
\hline \multirow[t]{2}{*}{ September 22 . } & 0 (check) & & $0.001^{*}$ & $\ldots \ldots$ \\
\hline & & September 19 & 0.035 & $\cdots \cdots$ \\
\hline \multirow{3}{*}{ September 28.} & 0 (check) & & 0.000 & $\ldots \ldots$ \\
\hline & 6 & September 19 & 0.036 & \\
\hline & 2 & September 5 & 0.028 & 0.0035 \\
\hline October $1 \ldots .$. & 3 & September 26 & 0.019 & 0.0010 \\
\hline \multirow{2}{*}{ October 6 . } & 0 (check) & & $0.001^{*}$ & $\ldots \ldots$ \\
\hline & 6 & September 19 & 0.038 & $\cdots \cdots$ \\
\hline October $\boldsymbol{\tau}$. & 3 & September 25 & 0.106 & 0.005 \\
\hline
\end{tabular}

* Some drift from adjacent dusted plots may have occurred.

boiled for 4 hours to concentrate the solids to a point comparable to hot sauce and catsup, the amount of residue for vines dusted with calcium arsenate was negligible. For vines dusted with barium fluosilicate the residue was well below the tolerance for fluorine. The results of these studies are summarized in tables 12 to 16 .

Apparently with modern washing machinery there is no serious residue problem in the case of camning tomatoes. If trimmings are used to make concentrates, there is a possibility that the finished product may contain fluorine or arsenic slightly in excess of 0.01 grains per pound. Any danger of this, however, could be overcome by dipping the fruit in a 1 per cent hydrochloric acid bath, before passing it through the regular cannery washer.

When dusting is done during harvest and the fruit is to be used for the green market, it may be necessary to wash or carefully wipe it. 
The legal tolerance for fluorine is at present the same as that for arsenic but there is some evidence that it should be less stringent : Marcovitch, Shuey, and Stanley (1937), after careful experimentation, concluded that there was considerable probability that greater tolerance should be allowed on fluorine.

\section{CAUTION}

Because the control of tomato pests involves the use of insecticides that are poisonous to men and animals, care should always be used in applying them. Workers applying insecticidal dusts should always be supplied with dust masks. There are types of masks on the market which cause the worker but slight inconvenience. Cattle and other animals should be kept away from freshly dusted fields.

It is very important that poison baits be kept out of the reach of children and chickens.

Care should be taken to see that fruit intended for the fresh market does not contain more than the legal amount of residue allowed by law.

\section{SUMMARY}

The corn earworm, Heliothis obsoleta (Fab.), is one of the most important insects attacking the tomato fruit. In the northern tomato-producing area of California, it passes through no less than three generations in a year. Where infestations are severe, more than 50 per cent of the fruit may be destroyed. Tomatoes are not the preferred host, and it is apparently necessary for the corn earworm to build up on such crops as sweet corn or beans before tomato plantings are seriously attacked. Consequently destructive infestations of the corn earworm in tomato fields are not encountered until the first of August and later. There are some areas where the corn-earworm infestation does not rise to a point justifying control measures. Dusting for the control of this serious pest can be delayed until 2 to 4 per cent of the developing fruits are infested. An experienced person can determine the degree of infestation by picking and carefully examining no less than 300 or 400 fruits $1 \frac{1}{2}$ to $2 \frac{1}{2}$ inches in diameter.

In experimental work, the following dusts gave good control : 40 per cent cryolite, 40 per cent barium fluosilicate, straight commercial calcium arsenate, and a 50 per cent lead arsenate. Dusts containing phenothiazine or cuprous cyanide gave some control but were not so effective as the arsenicals or the fluosilicates. Derris-sulfur dust and pyrethrum-sulfur dust proved ineffective, as did a dust containing Epsom salts.

Dusts applied under ideal weather conditions remain effective for from 3 to 4 weeks, and with the most severe infestations encountered not 
more than three dustings were necessary to protect the tomato crop. When the vines are large, calcium arsenate should be applied at the rate of 15 to 25 pounds per acre, and fluorine dusts at the rate of 30 pounds per acre.

Armyworms may at times cause serious damage, but most species can be successfully controlled with poison baits. The yellow-striped armyworm, Prodenia praefica Grote, which is sometimes very destructive to both the foliage and the fruit, cannot be controlled with poison baits scattered over the ground, but is effectively controlled with a dust such as calcium arsenate.

The tomato pinworm, Gnorimoschema lycopersicella Busck, one of the most destructive insects attacking the tomato fruit, does not do widespread damage in the northern tomato-producing area of California. It is known to occur about Merced and Modesto, and a very light infestation is present in the San Francisco Bay area. There is no successful chemical control for this pest, but the destruction of the tomato vines as soon as harvest is complete will aid in reducing losses.

The potato tuber moth, Gnorimoschema operculella (Zeller) (Phthorimaea), is widespread over a large portion of the tomato-growing area of California. It appears to be favored by the cool climate of the coastal regions. Severe damage has been observed only where tomatoes have followed potatoes or have been produced in areas devoted largely to potato culture.

Hornworms are among the most destructive insects attacking tomatoes. Both the foliage and the fruit are eaten. They are most destructive in the warmer interior valleys. When an infestation first develops, they can be held in partial check by hand-picking; later, dusting with calcium arsenate may be necessary.

Because tomatoes must be dusted during the harvest, there is a residue problem. Where fruit is delivered to the cannery, this need cause little concern, for the residue can be satisfactorily removed in canneries equipped with modern washing machinery. Where fruit is to be used for the green market, it should be washed or carefully wiped.

Because the control of caterpillars attacking tomatoes calls for the use of insecticides poisonous to men and animals, they should be applied with care. Men who work with dusts should be supplied with dust masks, and animals should be kept away from fields that have just recently been dusted. 


\section{ACKNOWLEDGMENTS}

These investigations have been made possible and greatly aided by a group of efficient coöperators, assistants, and other helpers.

The producers who furnished experimental plots of growing tomatoes and rendered special services in the harvesting of the crop are: Balfour, Guthrie Co., Brentwood; George Ballou, Santa Clara; California Packing Corporation, Union Island; L. L. Lauppe, Sacramento; Silveria Bros., San Jose ; and others.

Insecticide manufacturing companies furnishing materials for experimental purposes are : California Spray-Chemical Corp., Chipman Chemical Co., E. I. du Pont de Nemours \& Co., General Chemical Co., and others.

The Canners' League of California through F. A. Dixon, and the Western Branch Laboratory of the National Canners' Association through J. R. Esty, arranged and coöperated in making the canning tests. The analytical work on insecticidal residues was done in the National Canners' Association laboratory by W. F. Eberz and F. C. Lamb.

W. M. Hoskins and H. J. Lowe of this division, and J. E. Spurlock and L. M. McQuesten of the Agricultural Extension Service, rendered valuable assistance in the laboratory and field investigations.

A number of assistants from the W. P. A. rendered special services in connection with life-history studies in the laboratories.

To all these, and to others who have aided us, we extend thanks and appreciation. 


\section{LITERATURE CITED}

BAILEX, J. E.

1936. Tomatoes. Georgia Agr. Exp. Sta. Cir. 106:1-6.

BARBER, G. W.

1936. The corn earworm in southeastern Georgia. Georgia Agr. Exp. Sta. Bul. 192:1-18. 8 figs.

BISHOPP, F. C.

1922. The bollworm or corn earworm. U. S. Dept. Agr. Farmers' Bul. 872:1-15. 7 figs.

CaMpbeli, R. E., and J. C. Elmore.

1931. Damage to tomatoes in southern California by the tomato pinworm and the potato tuber moth. California State Dept. Agr. Mo. Bul. 20(7):458-60.

1935. The tomato pinworm. California State Dept. Agr. Mo. Bul. 24(3):301-9. 8 figs.

Davis, R. J., H. Spencer, and H. H. Zimmerley.

1924. Dusting and spraying tomatoes. Virginia Truck Exp. Sta. Bul. 46:317-27. 3 figs.

EDWARDS, W. H.

1935. Insect pests of tomato. Jamaica Agr. Soc. Jour. 39(9):565-68.

ELMORE, J. C.

1937. The tomato pinworm. U. S. Dept. Agr. Cir. 440:1-8. 4 figs.

Hansberry, T. R., and C. H. Richardson.

1936. Toxicity of certain stomach poisons to several common lepedopterous larvae. Jour. Econ. Ent. 29:1160-66.

HEADLEE, T. J.

1935. Derris as an arsenical substitute on vegetables. Jour. Econ. Ent. 28(3): 605-7.

Houser, J. S.

1936. Report of the tomato fruit worm investigations at Marietta. Ohio Veg. Growers' Assoc. Proc. 21:91-96.

Huckett, H. C., and G. E. R. HeRvex.

1935. Recent developments in the use of arsenical substitutes for vegetable pest control in New York. Jour. Econ. Ent. 28(3):602-3.

ISELY, D.

1935. Relation of hosts to abundance of cotton bollworm. Arkansas Agr. Exp. Sta. Bul. 320:1-30. 7 figs.

KADOw, K. J., and L. H. SHRopshIRE.

1935. Tomato diseases and insect pests. Illinois Agr. Exp. Sta. Cir. 428:1-36. 12 figs.

Knowlton, J. F., and C. F. Sмrтh.

1935. Tomato fruit worms. Utah Agr. Exp. Sta. Leaflet No. 61:1-4. 3 figs.

LANGE, W. H., and A. E. Michelbacher.

1937. Two closely related species of Heliothis found in tomato fields of Central California. California State Dept. Agr. Mo. Bul. 26(3):320-25.

Marcovitch, S., G. A. Shuey, and W. W. Stanley.

1937. Cryolite spray residues and human health. Tennessee Agr. Exp. Sta. Bul. 162:1-46. 
Morgan, W. L., and P. C. HeLy.

1936. Tomato fruit caterpillar. Control experiments with late autumn crops. New South Wales Agr. Gaz. 47(12):691-93. 1 fig.

Morrill, A. W.

1926. Airplane dusting for the control of vegetable pest on the Mexican west coast. Jour. Econ. Ent. 19(5):695-99.

Phillips, W. J., and G. W. Barber.

1933. Egg-laying habits and fate of eggs of the corn earworm moth and factors affecting them. Virginia Agr. Exp. Sta. Tech. Bul. $47: 1-14.1$ fig.

Roney, J. N., and F. L. Thomas.

1935. Arsenical substitutes for controlling vegetable insects. Jour. Econ. Ent. $28(3): 615-17$.

RusselL, T. A.

1933. Report of the Plant Pathologist. Bermuda Dept. Agr. Rept. 1933:28-36. SHERMAN, F.

1935. Tomato fruit worm. South Carolina Agr. Exp. Sta. Ann. Rept. 1934-35:55. Stanley, W. W.

1936. Studies of the ecology and control of cutworms in Tennessee. Tennessee Agr. Exp. Sta. Bul. 159:1-16. 5 figs.

Thomas, C. A.

1933. Observations on the tomato pinworm (Gnorimoschema lycopersicella Busck) and the eggplant leaf miner (G. glochinella Zeller) in Pennsylvania. Jour. Econ. Ent. 26(1):137-43. 1 fig.

1936a.-Status of the tomato pinworm (Gnorimoschema lycopersicella Busck) in Pennsylvania. Jour. Econ. Ent. 29(2):313-17.

1936b. The tomato pinworm (Gnorimoschema lycopersicella Busck). Pennsylvania Agr. Exp. Sta. Bul. 337:1-15. 3 figs.

THOMAs, F. L.

1936. Non-poisonous insecticides for use on vegetable crop. Market Growers Jour. 58(2): 1. Louisville, Ky.

Thomas, F. L., and E. W. Dunnam.

1931. Factors influencing infestation in cotton by Heliothis obsoleta Fab. Jour. Econ. Ent. 24(4):815-21.

VECHT, J. VAN DER.

1936. Proeven met derris tegen insectenplagen in Nederlandsch-Indië [Experiments with derris against insect pests in the Netherlands Indies]. Landbouw; Landbouwkundig Tijdschrift voor Nederlandsch-Indië [Buitenzorg, Java] 11:401-65. Abstracted in: Rev. Appl. Ent. Ser. A, 24:765-66.

VEITCH, R.

1935. Corn earworm. Queensland Agr. Jour. Ser. 2, 44(3):280-85.2 pl. with 13 figs. WALKER, H. G., and L. D. ANDERson.

1935. Summary of results obtained with arsenical substitutes for the control of vegetable crop insects at the Virginia Truck Experiment Station. Jour. Econ. Ent. 28(3):603-5.

WATSON, J. R.

1912. Tomato insects. Florida Agr. Exp. Sta. Bul. 112:1-39. 14 figs. 